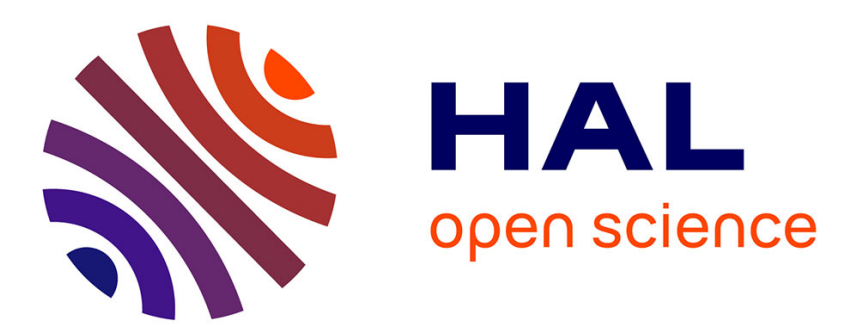

\title{
Coastal Quaternary morphologies on the northern coast of the South China Sea, China, and their implications for current tectonic models: A review and preliminary study
}

Kevin Pedoja, Jian-Wei Shen, Steve Kershaw, Cheng Tang

\section{To cite this version:}

Kevin Pedoja, Jian-Wei Shen, Steve Kershaw, Cheng Tang. Coastal Quaternary morphologies on the northern coast of the South China Sea, China, and their implications for current tectonic models: A review and preliminary study. Marine Geology, 2008, 255, pp.103-117. 10.1016/j.margeo.2008.02.002 . hal-00358775

\section{HAL Id: hal-00358775 \\ https://hal.science/hal-00358775}

Submitted on 23 Sep 2019

HAL is a multi-disciplinary open access archive for the deposit and dissemination of scientific research documents, whether they are published or not. The documents may come from teaching and research institutions in France or abroad, or from public or private research centers.
L'archive ouverte pluridisciplinaire HAL, est destinée au dépôt et à la diffusion de documents scientifiques de niveau recherche, publiés ou non, émanant des établissements d'enseignement et de recherche français ou étrangers, des laboratoires publics ou privés. 


\title{
Coastal Quaternary morphologies on the northern coast of the South China Sea, China, and their implications for current tectonic models: A review and preliminary study
}

\author{
Kevin Pedoja ${ }^{a, *}$, Jian-Wei Shen ${ }^{\text {a }}$, Steve Kershaw ${ }^{b}$, Cheng Tang ${ }^{\text {a }}$ \\ a Laboratory of Marginal Sea Geology, South China Sea Institute of Oceanology and Guangzhou Institute of Geochemistry, Chinese Academy of Sciences, 164 West Xingang Road, \\ 510301 Guangzhou, PR China \\ b Institute for the Environment, Brunel University, Uxbridge, Middlesex, UB8 3PH, UK
}

\begin{abstract}
Marine terraces, tidal notches and sediments along a 1200-km-long stretch of the northern coast of the South China Sea passive margin were studied and divided into five areas with varying tectonic characters. Up to three marine terraces occur, that have elevations reaching up to $60 \mathrm{~m}$ above mean sea level (amsl), and two marine notches occur up to $11 \mathrm{~m}$ amsl. Chronology of the morphologies and deposits was obtained mainly by comparison with Quaternary sea levels derived from the oxygen isotope curve. However, prior to the last interglacial highstand (MIS 5e, c. $125 \mathrm{ka}$ ), evidence of history of events is less well-constrained, leading to less precision on sea-level positions prior to MIS 5e. Using the morphological features of MIS 5e as a marker, mean coastal uplift rates in the last c. $125 \mathrm{ka}$ range from $0.07 \mathrm{~mm} / \mathrm{yr}$ to $0.18 \mathrm{~mm} / \mathrm{yr}$. The pattern of deformations is slightly higher than those observed on passive margin coasts in other parts of the world. The cause of uplift of the south China coastline is not clear, but may relate to the Himalayan collision zone or any other large-scale phenomena.
\end{abstract}

\section{Introduction}

Since the 1960s the formation and evolution of coasts have been interpreted to result from the combination of eustasy and tectonics combined with the local setting: climate, oceanography, and rock types that form the coastline (Herbert-Veeh, 1966). Uplifted marine terrace sequences may be considered the geomorphic record of repeated glacioeustatic sea-level highstands superimposed on a rising coastline (Bull, 1985). Positive vertical movements have been quantified on different coasts of the world through the study of marine terraces and notches (see Johnson and Libbey, 1997, for a review). In contrast to active areas, Pleistocene rocky shores on passive margins are rarely reported in the literature, except in areas of large-scale isostatic rebound following deglaciation, such as in northern Europe (e.g. Lowe and Walker, 1997). Because a passive margin is a continental margin, which does not coincide with the junctions of tectonic plates, generally few or no tectonic movements are observed on such coasts in far-field sites (far from glacial centers). The northern coast of the South China Sea passive margin is a non-glaciated coastline, but demonstrates tectonic motion that is not understood owing to the lack of data and dates. Although uplift

\footnotetext{
* Corresponding author. Present address: Laboratoire Morphodynamique Continentale et Côtière, 2-4, Rue des tilleuls, Université de Caen (Campus 1) 14000 Caen cedex, France. Tel.: +332315657 17; fax: +33231565757.

E-mail address: kevin.pedoja@unicaen.fr (K. Pedoja).
}

is recognized (Zong, 2004; Yim et al., 2006, this study) there is limited knowledge of Pleistocene terraces in the region. The northern coast of the South China Sea is composed of various rocks, primarily Palaeozoic to Mesozoic granitic and metamorphic rocks but also Mesozoic to Cenozoic basaltic rocks to the north (Hainan Island) and a thin cover of Quaternary sediments in some places (mainly Hainan) (Wang et al., 2000).

The principal aim of this paper is to assess the application of marine terrace data on the northern coast of the South China Sea in order to interpret the recent tectonic history of the coastal areas. An attempt is made to correlate the terraces with known Pleistocene highstands in the region; data are better quality for the more recent history, since the last interglacial highstand (MIS 5e, c. $125 \mathrm{ka}$ ). The resulting uplift rates are therefore interpreted in order to improve the knowledge of coastal tectonics and Pleistocene sea-level highstands on the passive margin of the northern part of the South China Sea. Much of the background information was previously available in Chinese, and so a secondary aim of this paper is to open this information to non-Chinese readers.

\section{Regional tectonic background}

\subsection{Geodynamics and geology}

East and Southeast Asia is a geodynamically complex zone (Fig. 1). At a regional scale, the major event consists of the collision of the India 


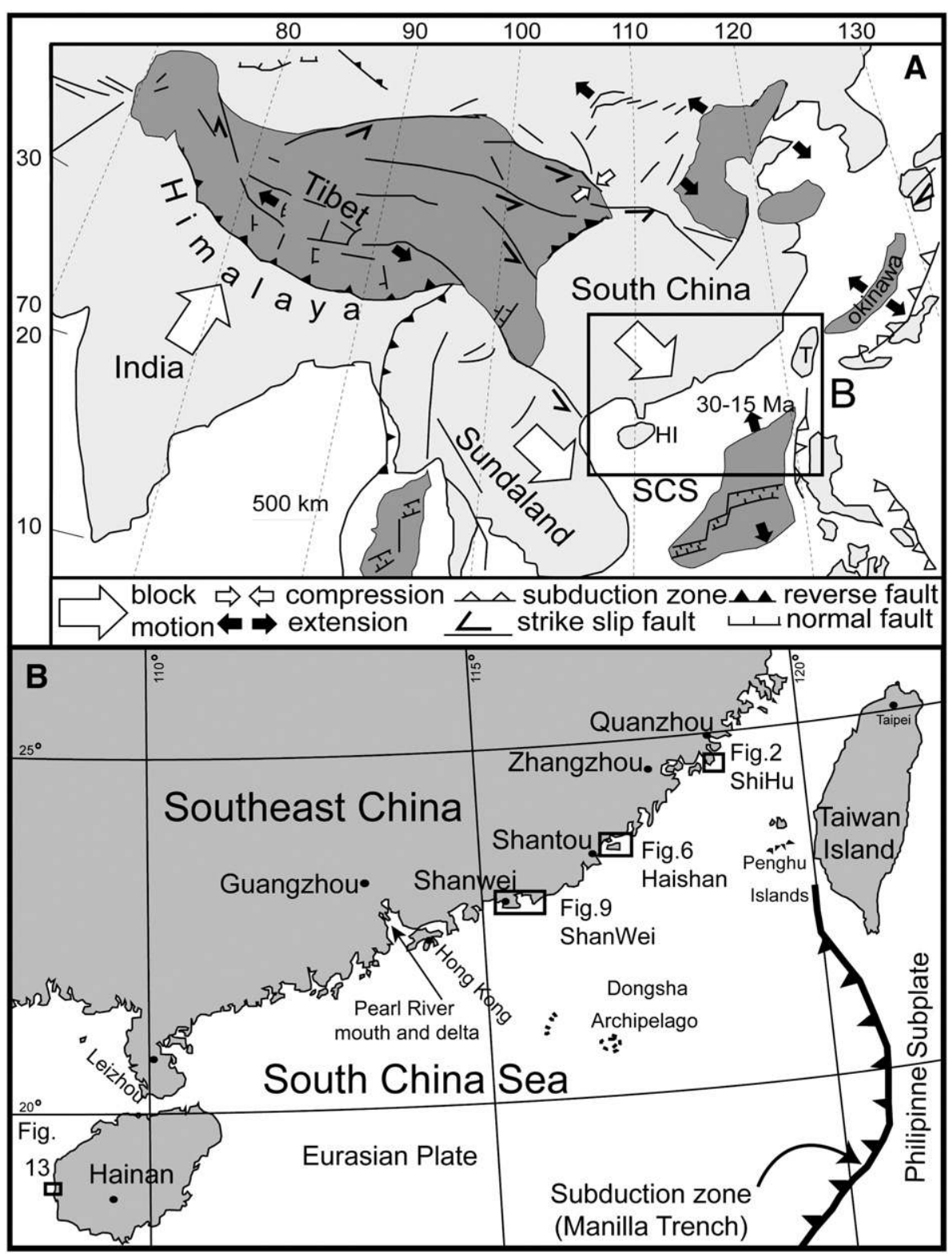

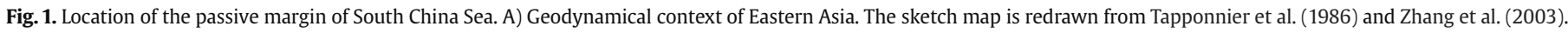
HI: Hainan Island. T: Taiwan. B). Studied zone on the northern Coast of the South China Sea.

and Eurasian Plates (Fig. 1A) with ongoing orogenesis of the Himalayas and important tectonic stress distributed on a zone extending $60^{\circ}$ to $130^{\circ} \mathrm{W}$ (Morley, 2002; Tapponnier et al., 1986, Zhang et al., 2003). To the east, this major collision results in the extrusion of continental blocks (Sundaland and South China on Fig. 1A) (Morley, 2002; Zhang et al., 2003). The northern part of the South China Sea coast lies on the eastern part of the Eurasian Plate that faces the Pacific Plate and the Philippine Subplate to the East, and is bounded to the west by the ongoing Himalayan orogenesis (Fig. 1A). The Philippine Subplate (of the Pacific Plate) slides underneath the Eurasian Plate at a rate of $5.6 \mathrm{~cm} / \mathrm{yr}$ (Sibuet and Hsu, 2004).

Since the Mesozoic, this continental margin went through a succession of geotectonic regimes: from an active Andean type margin during the Cretaceous, to a divergent rift, to a passive continent margin since Palaeogene times (for a recent synthesis see Lüdmann and Wong, 1999).

Very little is known about the active tectonics of the northern coast of the South China Sea. The zone between the Pearl River mouth and the Taiwan Strait (Fujian and east Guangdong Provinces) is characterized as a relatively narrow continental shelf. This area is inferred to be influenced by little tectonic movement (Zong, 2004). The zone southwest of the Pearl River mouth (west Guangdong and Hainan Island) lies further away from the plate boundary and is considered tectonically stable (Huang et al., 1986). These two zones are separated by the Pearl River delta (Fig. 1B) interpreted to have experienced subsidence caused mainly by fault activity (Zong, 2004).

The northern South China Sea is dominated by three major fault systems: 1) a normal NE-SW trending system which has been active during the rift phase (late Cretaceous through Oligocene Time) (for example Yu, 1990, 1994). The extensional movements associated with the rifting (NW-SE) present an increasing intensity towards the south and the west. 2) a normal E-W to ENE-WSW trending system developed between the Late Eocene and the Early Miocene (Yu, 1990, 1994) and 3) a sinistral strike-slip NW-SE system which is associated with the Red River Fault (Lüdmann and Wong, 1999) and is currently active as shown by earthquake focal mechanisms (Wei and Chung, 1995). On the northern continental margin of the South China Sea, Lüdmann et al. (2001) attempted to derive a neotectonic curve by subtracting eustatic sea-level changes from the relative sea-level curve. Although there is no agreed eustatic curve, Lüdmann et al.'s 
(2001) work shows that the depths of the delta fronts today are controlled by regional tectonic movements and global sea level. The ocean south of Hong Kong and around the Dongsha Archipelago (Fig. 1B) has been interpreted to have undergone two uplift episodes during the past 5 million years; at the Miocene/Pliocene boundary and the end of Lower Pleistocene, leading to subaerial exposure of the Dongsha rise (Lüdmann et al., 2001), see Fig. 14. After the major collision of Taiwan with the East China continental margin 5 Ma ago (Mio/Pliocene boundary), the NNW-WNW compression was turned into a WSW-SSW strike-slip motion along the continental margin of the northern South China Sea, generating a transtensional tectonic regime which activated and reactivated crustal zones of weakness, and caused upwelling of mantle material and magma intrusion into the upper crust and uplift of the caprocks (Lüdmann and Wong, 1999) (see the Hainan and Wenshan uplift on Fig. 14).

\subsection{Holocene RSL}

Little is published in English on Holocene relative sea-level and/or coastal tectonics of continental China (e.g. Zong, 2004) compared to Taiwan (Liew et al., 1990, 1993, 2004; Liew and Hsieh, 2000; Chen and Liu, 1996, 2000; Chen et al., 2004; Hsieh et al., 2004; Song et al., 2004; Yamaguchi and Ota, 2004), Hong Kong (Owen, 1995; Davis, 1999, 2000; Yim, 1999; Fyfe et al., 2000, Yim and Huang, 2002, 2003; Baker et al., 2003;) or South Korea (Kim and Lee, 2006). For the southern Fujian province, Xie et al. (1985) stated that sea level fluctuated from 8000 to $7000 \mathrm{yr}$ B.P. and rose rapidly $6000-5000$ and $3500-2500$ yr B.P. The maximum transgression with a 3-5 m high sea level occurred 4000$3000 \mathrm{yr}$ B.P. Other authors (Huang and Zhu, 1985) studied the development of tombolo in the southern part of Hainan Island proposed a $5 \mathrm{~m}$ higher middle Holocene highstand. Field observation revealed the important development of tombolo and recent sand deposits (see Figs. 2, 5,7 , and 10) on the China Coast. Frequently granitic islands are linked to the continent by sand deposits (see description of Shihu micropeninsula, Fig. 2), the coastal morphology can be easily explained if middle Holocene highstands are interpreted. The regression would have led to the deposition of sand that would create those morphologies. In this paper, we recognize at least two relative highstands above present sea level, one at $+4( \pm 1) \mathrm{m} \mathrm{c}$. $5000 \mathrm{yr}$ BP, and another at $1.5( \pm 1) \mathrm{m} \mathrm{c}$. $3000 \mathrm{yr}$ BP as in the complex sea-level curve proposed by Xie et al. (1985) and bettered by Huang and Zhang (2005). However, the curve provided by Baker et al. (2003) is probably the most accurate because of its dependence of fixed biological indicators (FBIs); these give a much more reliable position of sea level because of the fixed nature of encrusting organisms. Baker et al. (2003) recognised a mid-Holocene highstand of only $+2 \mathrm{~m}$ above moderns sea level at c. $5000 \mathrm{yr}$ BP, giving uplift rates approximately half of those derivable from the Huang and Zhang (2005) curve. Nevertheless, the occurrence of mid-Holocene highstands remains problematic on the coast of continental China (for a recent synthesis see Zong, 2004), but have been observed to the north and to the south in the Penghu Islands (Chen and Liu, 1996) and the Red River Delta (Hori et al., 2004; Lam and Boyd, 2003; Tanabe et al., 2003) respectively. They are concordant with coastal morphologies (i.e. Holocene deposits, tombolos). This interpretation of two Holocene highstands partially agrees with the sea-level changes in the Indo-Pacific (Woodroffe and Horton, 2005) and in the general shape agree with the summary of oscillating regression models from sea-level index points created using fixed biological indicators from another far-field location (as defined by Pirazzoli, 1991, 1993), in southeastern Australia (Baker et al., 2001). Nevertheless, Baker et al. (2003) interpreted only one Holocene highstand, c. 5000 yr BP, identified also by Beaman et al. (1994) on the east coast of Australia; so the issue remains controversial.

Recognition and estimation of magnitude of the mid-Holocene high sea level has some implication for the Holocene sea-level history of the south China coastline. However, over the longer time period to MIS 5e, the effect of variations in calculation of Holocene sea levels has little influence of the calculation of rates of Pleistocene sea levels. This is because the issue of interplay between sea-level change and uplift rates for the Holocene only apply to the last $5000 \mathrm{yr}$, which is only a small fraction of the total uplift since MIS 5 e.

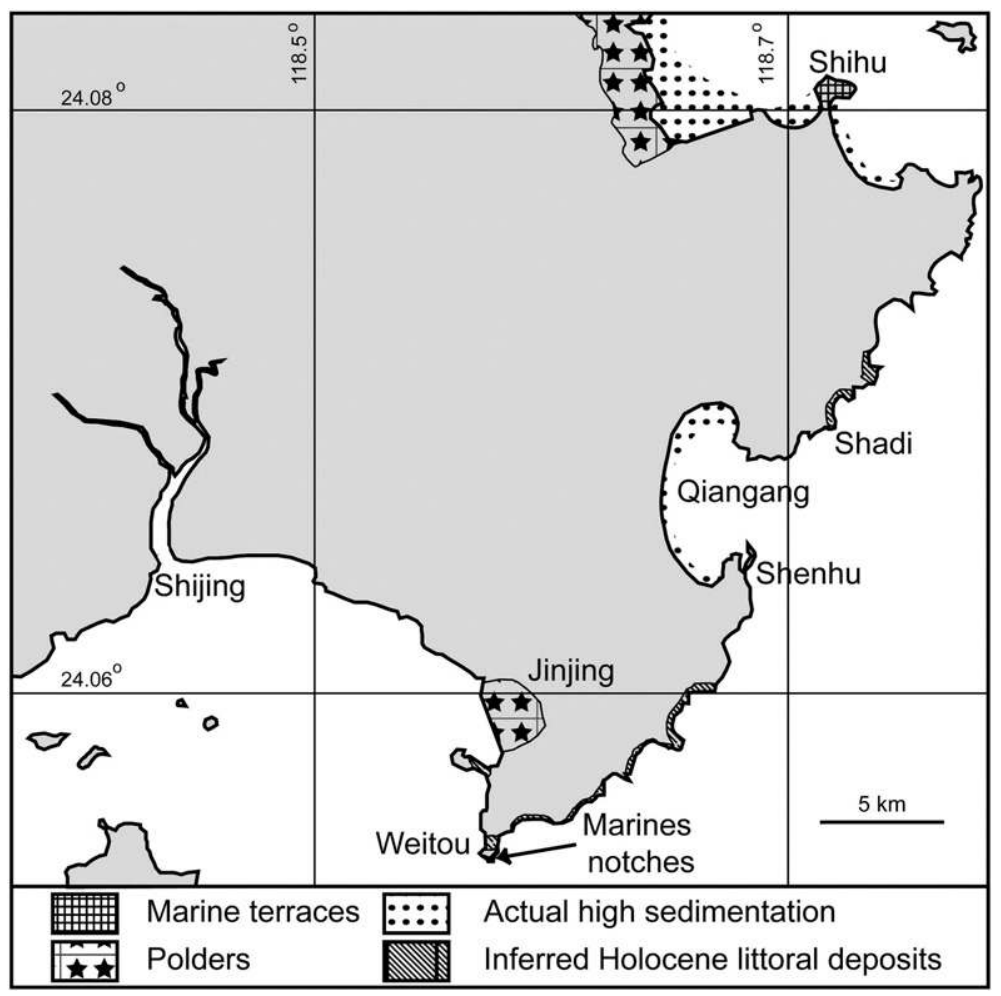

Fig. 2. Marine terraces (Sequence A) and marine notch sequences on the Jinjing Peninsula (Fujian province). 


\section{Materials and methods}

On uplifting coasts, marine terrace sequences are sometimes represented by flights of "stairs" up to hundreds of meters in altitude above mean sea level. Each terrace corresponds to a gently seawarddipping erosional or depositional platform backed by a relict sea cliff. The shoreline angle (i.e. intersection of the relict platform and the relict sea cliff) provides a good approximation of the location and elevation of a former shoreline and hence a relative sea level (Carter and Woodroffe, 1994). It is now widely viewed that marine terraces are formed during the separated highstands of interglacial stages correlated to Marine Oxygen Isotopic Stages (MIS) (James et al., 1971; Chappell, 1974; Bull, 1985; Ota, 1986; Jouannic et al., 1988; Muhs et al., 1990). The total displacement of the shoreline relative to the age of the associated interglacial stage allows calculation of a mean uplift rate. However, just because it is logically true that terraces are correlated to the MIS, it does not prove that they actually were; so, in this study we correlate them to the oxygen isotope curve, subject to testing in a future paper. In order to estimate vertical uplift, the eustatic position of the considered paleo sea levels relative to the present one must be known as precisely as possible. Our chronology relies principally on relative dating based on geomorphologic criteria but in all cases we associated the shoreline angle of the marine terraces with numerical ages. The best-represented terrace worldwide is the one correlated to the last interglacial maximum (MISS 5e) (Hearty and Kindler, 1995; Johnson and Libbey, 1997; Pedoja et al., 2006a,b,c). Age of MISS 5e is arbitrarily fixed to range from 130 to 116 ka (Kukla et al., 2002) but is demonstrated to range from 134 to $113 \mathrm{ka}$ in Hawaii and Barbados

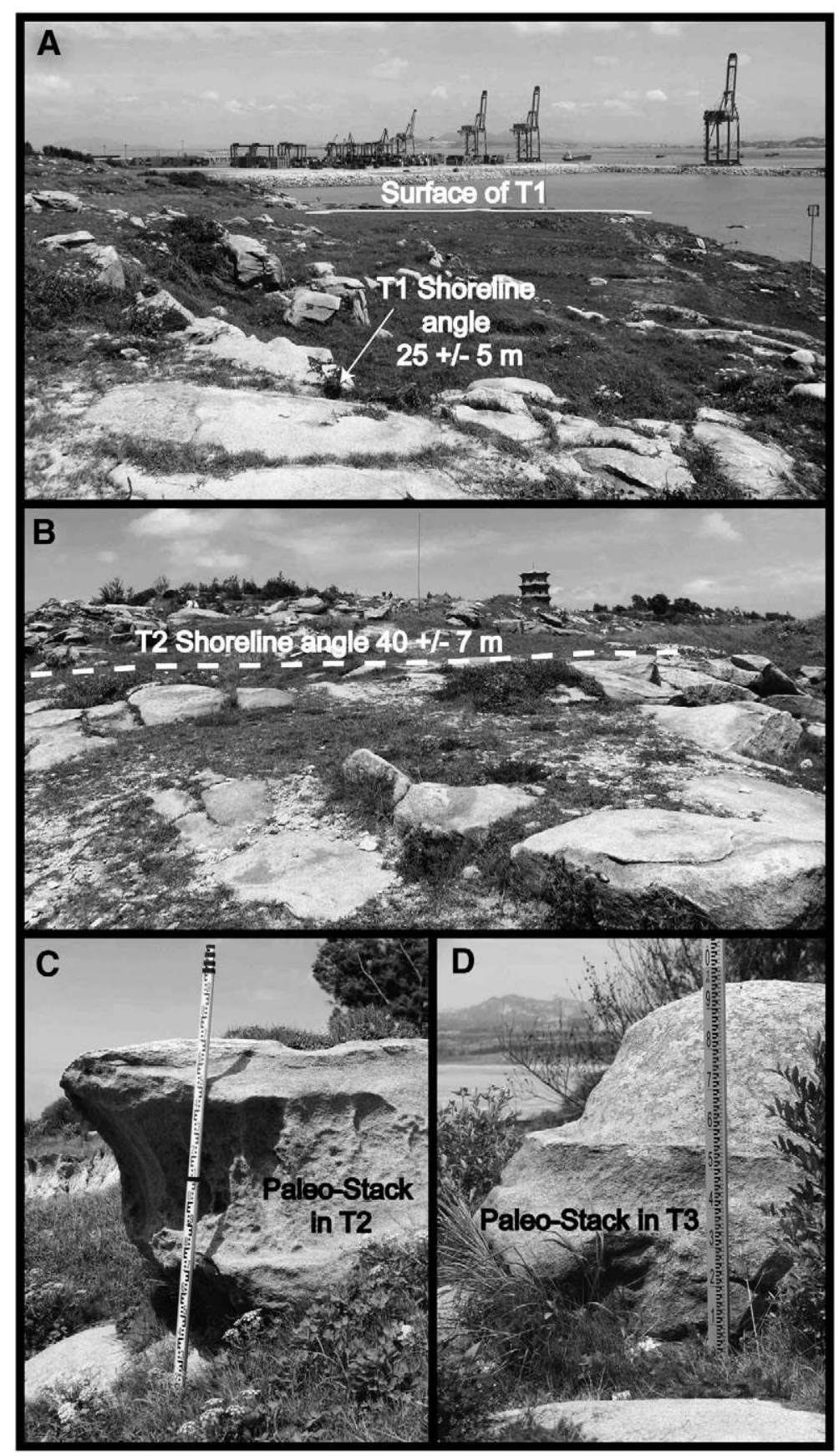

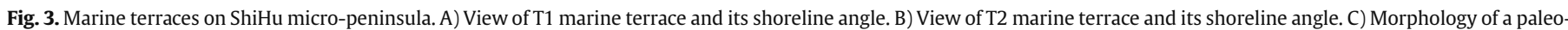
stack in T2 (altitude $37 \mathrm{~m}$ ). D) Morphology of a paleo-stack in T3 (altitude $57 \mathrm{~m}$ ). 


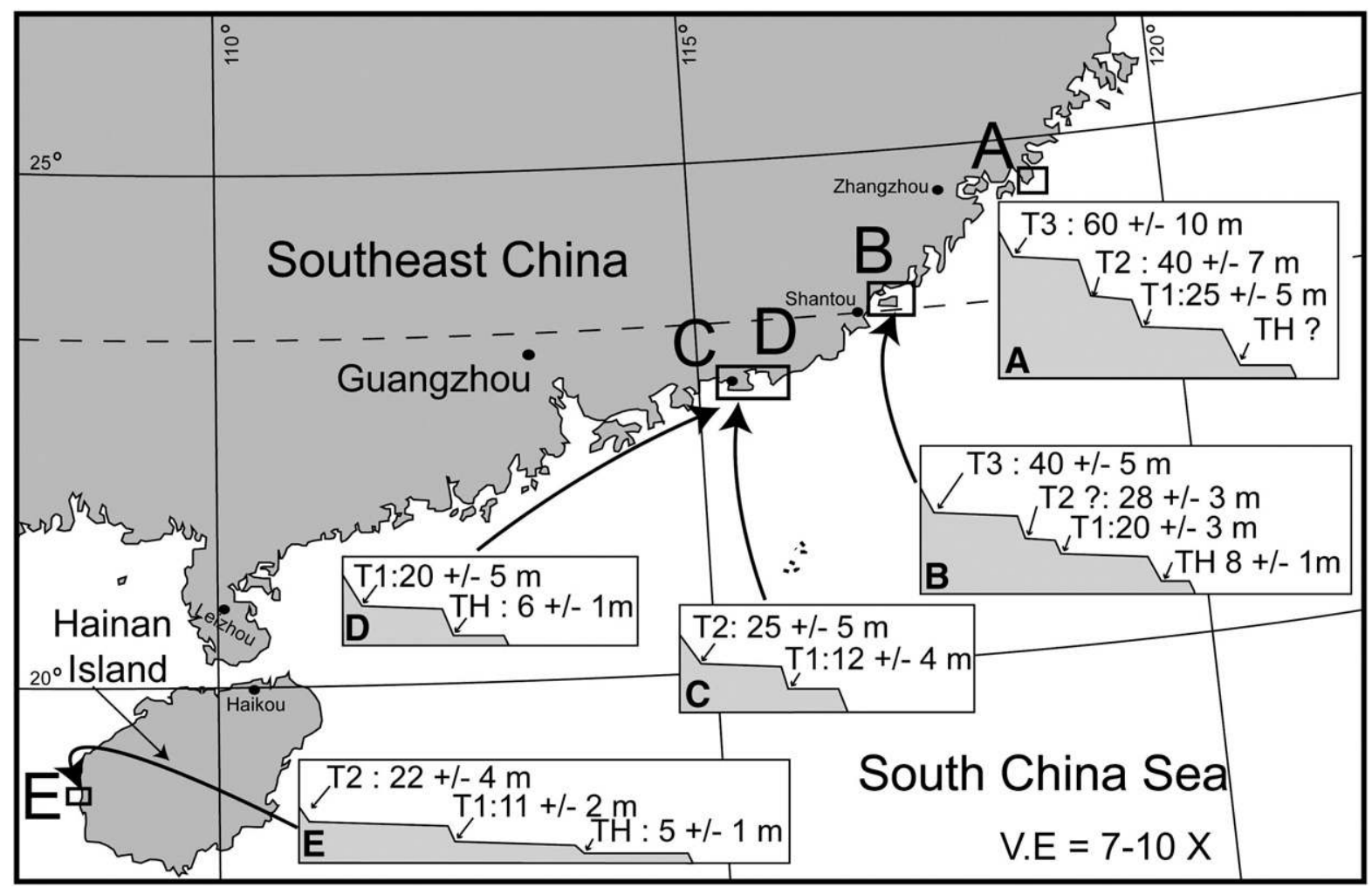

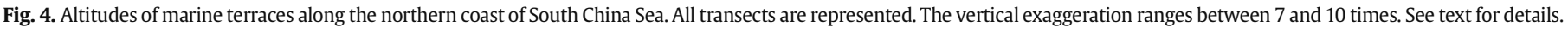

(Muhs, 2002) with a peak from 128 to 116 ka on tectonically stable coastlines (Muhs, 2002). Older marine terraces well represented in worldwide sequences are those related to MIS 9 ( 303-339 ka) and 11 ( 362-423 ka) (Imbrie et al., 1984). Compilations show that sea level was $3 \pm 3 \mathrm{~m}$ higher during MISS 5e, MIS 9 and 11 than during the present one and $-1 \pm 1 \mathrm{~m}$ to the present one during MIS 7 (Hearty and Kindler, 1995, Zazo, 1999). Consequently MIS 7 ( 180-240 ka; Imbrie et al.,1984) marine terraces are less pronounced and sometimes absent (Zazo, 1999). Because the elevations of these terraces are higher than the uncertainties in paleo-eustatic sea level mentioned for the Holocene and Late Pleistocene, these uncertainties have no effect on overall interpretation.

Uplift can also be registered through tidal notch sequences. Notches are often portrayed as lying at sea level; however notch types actually form a continuum from wave notches formed in quiet conditions at sea level to surf notches formed in more turbulent conditions and as much as $2 \mathrm{~m}$ above sea level (Pirazzoli et al., 1996 in Rust and Kershaw, 2000). As stated above, there was at least one higher sea level during the Holocene, so that some notches may not contain a tectonic component in their formation.
In 2005, during several field visits, the altitudes of the shoreline angles were measured using digital altimeters calibrated on the last high tide mark observed on the shore. The precise $0 \mathrm{~m}$ sea level is then determined using the tide tables of the China tidal gauge. We assume that the marine terraces, notches and coastal sandy deposits were formed under tide conditions similar to the modern. Note, however, that controlling processes on notches in granites may not be as wellconstrained as those in limestones. In fact, notches in granites identified in this paper are secondary in importance to the terraces, because of the lack of published data on formation of notches in granites. Barometric drift was registered using another altimeter displayed in a steady position at or near the reference point on the shore. All altitudes are given in meters above mean sea level (amsl). The error range with the altimeter is $\pm 1 \mathrm{~m}$, but the major error comes from the preservation quality of the shoreline angle. Erosion and/or anthropization tend to reduce the accuracy of measurement. Field techniques also included topographic surveys of Holocene beach, platform and notches. The whole zone is micro to meso tidal (Woodroffe, 2003) and the sea-level reference corresponds to the mean sea level. The Principal Datum (PD) of China consists in the LAT

Table 1

Measured shoreline angles and calculated uplift rates for marine terraces

\begin{tabular}{|c|c|c|c|c|c|c|c|c|c|}
\hline \multirow[t]{3}{*}{ Transect } & \multicolumn{4}{|c|}{ Shoreline angle elevation } & \multicolumn{5}{|c|}{ Calculated uplift rates (preferred hypothesis in bold italic) } \\
\hline & \multicolumn{4}{|l|}{$\overline{(\mathrm{m})}$} & \multicolumn{5}{|l|}{$(\mathrm{mm} / \mathrm{a}$ or $\mathrm{m} / \mathrm{ka})$} \\
\hline & $\overline{\mathrm{H}^{\mathrm{a}}}$ & $\mathrm{T} 1$ & $\mathrm{~T} 2$ & T3 & For T1 = MISS $5 \mathrm{e}^{\mathrm{b}}$ & For $\mathrm{T} 2=$ MISS $5 \mathrm{e}^{\mathrm{b}}$ & For $\mathrm{T} 2=\mathrm{MIS} 7^{\mathrm{c}}$ & For $\mathrm{T} 2=$ MIS $9^{\mathrm{c}}$ & For T3= MIS $9^{c}$ \\
\hline$\overline{\mathrm{A}}$ & nd & $25 \pm 5$ & $40 \pm 7$ & $60 \pm 10$ & $0.10-0.26$ & nd & $0.12-0.26$ & nd & $0.13-0.23$ \\
\hline B & $8 \pm 1$ & $20 \pm 3$ & $28 \pm 3 ?$ & $40 \pm 5$ & $0.08-0.20$ & nd & $0.10-0.18$ & nd & $0.08-0.14$ \\
\hline $\mathrm{C}$ & nd & $12 \pm 4$ & $25 \pm 5$ & & $0.01-0.14$ & $0.10-0.26$ & $0.08-0.17$ & nd & \\
\hline $\mathrm{D}$ & $6 \pm 1$ & $20 \pm 5$ & & & $0.08-0.22$ & nd & & & \\
\hline E & $5 \pm 1$ & $11 \pm 2$ & $22 \pm 4$ & & $0.02-0.11$ & nd & $0.07-0.15$ & $0.03-0.08$ & \\
\hline
\end{tabular}

nd $=$ not determined near this transect.

a Holocene-not all Holocene measurements are exactly on the same transect, but they are nearby, and in the same geographic order.

b MISS 5e is considered to have occurred between 134 and $113 \mathrm{ka}$ with an eustatic sea level of $3 \pm 3 \mathrm{~m}$.

c Considered range of ages for MIS 7 and 9 are 180-240 ka and 303-339 ka respectively. Sea levels of $3 \pm 3 \mathrm{~m}$ is considered for MIS 9 and $-1 \pm 1 \mathrm{~m}$ for MIS 7 . 

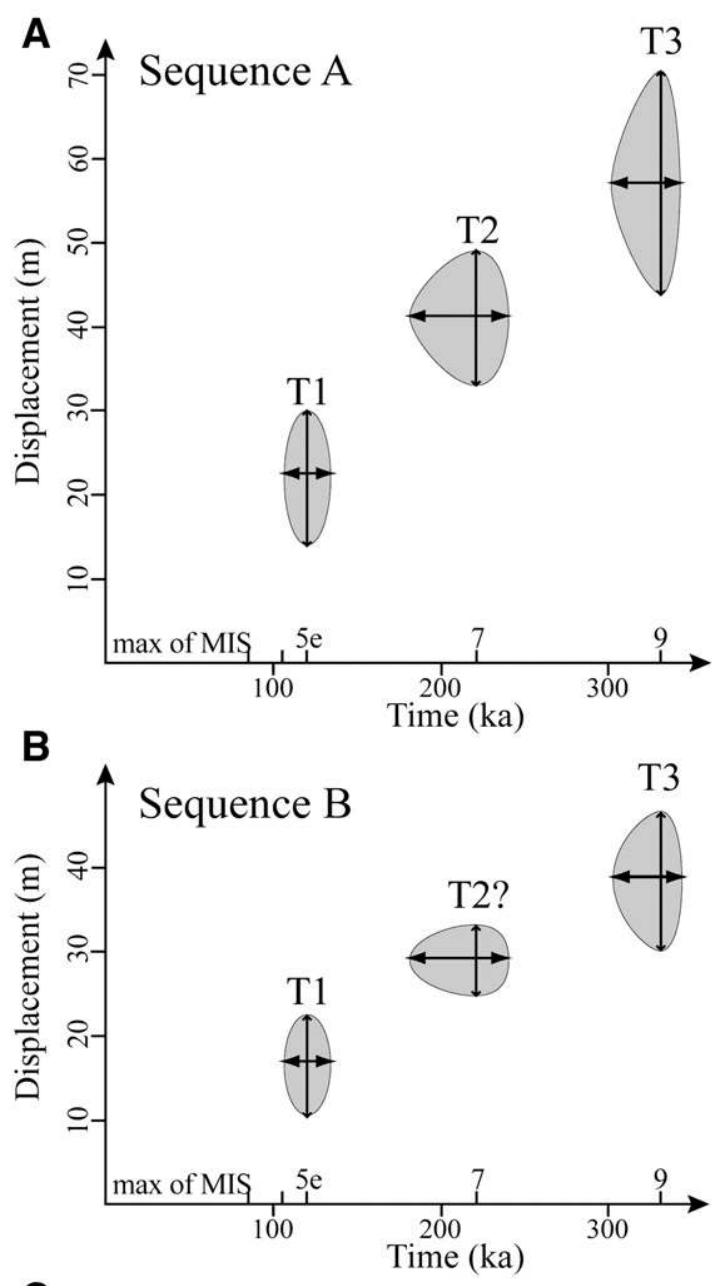

C

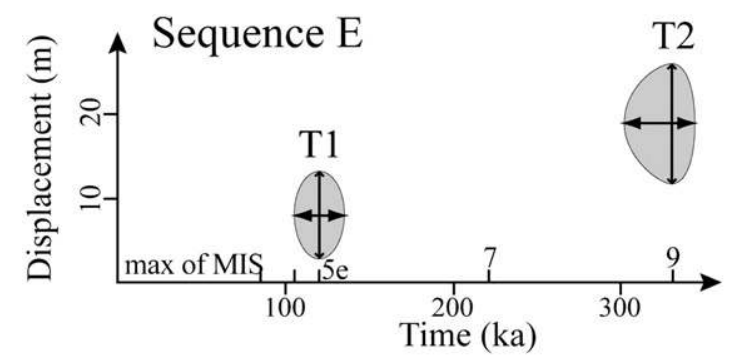

Fig. 5. Graphic representation of the uplift rates deduced from marine terraces along the northern coast of South China Sea. A) Sequence A, ShiHu micro-peninsula. B) Sequence B, NE Haishan Island. C) Sequence E, western part of the Hainan Island, North of Dongfang City.

(Lowest Astronomical Tides) of the Yellow Sea. Preliminary C14 analyses were performed in the Geochemistry laboratory of the Guangzhou University of Geography. It is important to note that the results of radiocarbon analysis have been reported without reference to the laboratory name or laboratory numbers. Other than the knowledge that the analyses were conducted in this laboratory, information such as laboratory codes, $\delta^{13} \mathrm{C}$ values are missing, limiting the possibility of further calibration.

\section{Results}

\subsection{Coastal morphologies and deposits along the South China Sea Coast}

The northern coast of the South China Sea extends southwestnortheast (Fig. 1B). Marine terraces and notch sequences have been investigated along a total $1200-\mathrm{km}$ stretch of the coast of the Fujian, Eastern Guangdong and Hainan Provinces with the exception of southwest Guangdong. Marine terraces have been found in four places (Fig. 1B) which are from northeast to southwest: 1) Shihu on the Jinjing peninsula (Fujian Province), 2) Haishan Island (Guangdong Province) 3) Zhelang and Shigongliao on the Shanwei peninsula and 4) on the western side of the Hainan Island. With exception of the Hainan Island (Wang et al., 2000), this is the first description and interpretation of these Chinese marine terraces sequences in English. The marine terraces sequences herein considered as Late Pleistocene in age (see below for details) are frequently associated with Holocene notches sequences and/or littoral deposits. Except in Hainan Island, total coastal retreats generally are on the order of $0.5-1 \mathrm{~km}$, the terraces being narrow because of the hardness of the basement. We describe the main sequences of terraces and notches from northeast to southwest.

On the northern coast of the South China Sea some problems are specific to particular sites (for a general description see Morton and Blackmore, 2001). Firstly, the lithology constitutes a limiting factor for the study of coastal morphologies. The northern coast of the South China Sea lacks limestone in which notches, marine terraces and other abrasion and/or dissolution features are easily carved (Kershaw and Guo, 2001). As a result we observed the poor development of notches and marine terraces and also the currently forming platform. Another limiting lithologic factor is the development of aeolian deposits that mask the coastal morphologies and cover the shallow marine and/or beach deposits (Wu and Wang, 1985). However, the most important problem is human degradation of the coastline: between 24 and $41 \%$ of the Chinese population live in the coastal zone, which produces $66 \%$ of the GDP (for more detail see Lau, 2005 and for an example see the factories on Fig. 3A). The land occupation results in the total destruction of coastal morphologies and deposits as raw material for building is needed (sand for cement, rocks for construction) or in the modification of the coastal zone for human living and economy (polders). Fish/clams farming and intertidal mud flats cover much of the South China Sea coast (Shi and Chen, 1996). As noticed by Yim (1999) for the Hong Kong region, the influence of humans through accelerated soil erosion, ground water pumping and coastal land reclamation have made it more difficult to see clearly minor variations in eustatic sea level.

\subsubsection{ShiHu marine terraces, Sequence A (Jinjing peninsula)}

ShiHu peninsula is a micro-peninsula on the northern margin of Jinjing peninsula, which lies east of the Shijing Estuary (Fig. 2). The ShiHu micro-peninsula (1.5 km wide and $1.2 \mathrm{~km}$ long) is a former granitic Island connected to the continent by a sandy tombolo, and contains a sequence of three marine terraces that cover the micropeninsula. Also, a sequence of 2 notches above the modern one is observed in Weitou, $35 \mathrm{~km}$ to the south of ShiHu. In between these two zones, some low sandy deposits are probably littoral in origin and may be Holocene in age (Fig. 2). In ShiHu peninsula, terraces are best preserved in its northern part. In this zone, the marine terraces carved in granites are narrow and reach a maximum altitude of $60 \pm 10 \mathrm{~m}$ (Figs. 3 and 4, Table 1). The lowest and youngest T1 marine terrace, which is the best preserved, has a maximum width of $60 \mathrm{~m}$. The T1 shoreline angle is noticeable in the landscape (Fig. $3 \mathrm{~A}$ ) at an altitude at $25 \pm 5 \mathrm{~m}$. The important margin of error ( $1 / 5$ of the measurement) is due to the fact that the shoreline angle precise location (and therefore altitude) is not easy to determine: as observed on the actual platform, the hardness of basement results in the carving of very irregular platform. The second marine terrace, T2, is also narrow and its shoreline is even more difficult to determine precisely. Evidence of this terrace is present between 33 and $47 \mathrm{~m}$ so an altitude of $40 \pm 7 \mathrm{~m}$ is applied here (Fig. 3B and C, Fig. 4, Table 1). The uppermost terrace (T3) constitutes the upper and wide surface of the micro-peninsula where the Pagoda has been built. Paleo-stacks are found up to the top at an 


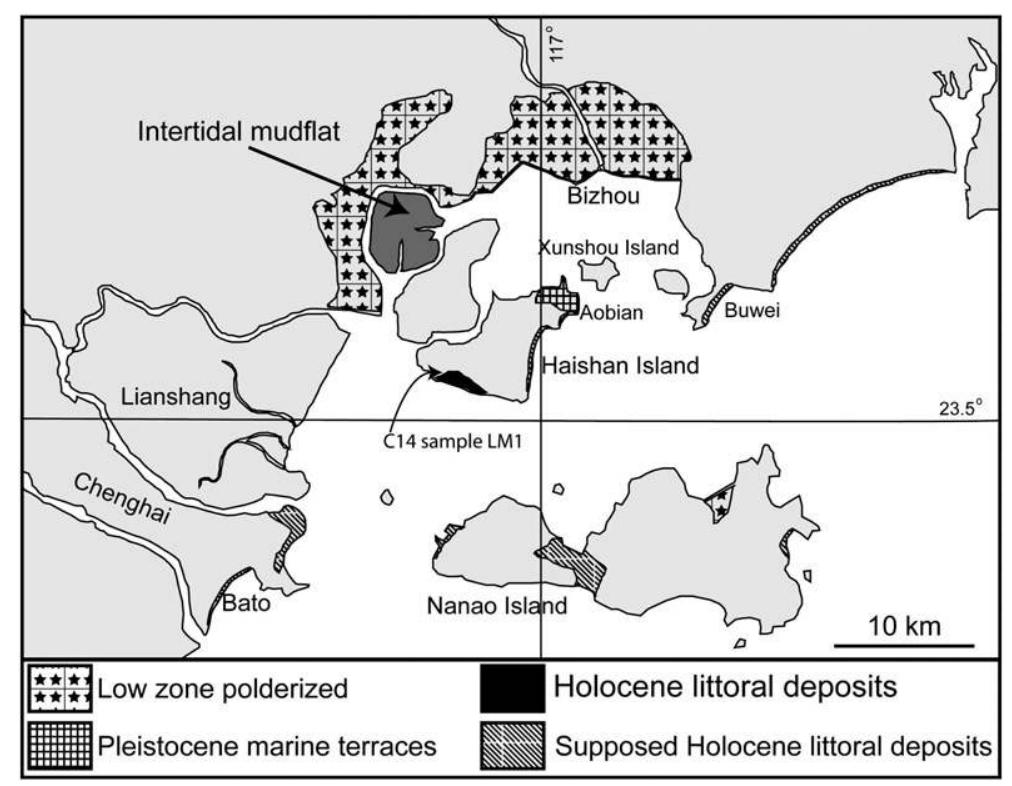

Fig. 6. Marine terraces (Sequence B) and Holocene littoral deposits on Haishan Island and its vicinity.

altitude of $57 \mathrm{~m}$ (Fig. 3D), so we estimate the paleo-shoreline associated to T3 to be at $60 \pm 10 \mathrm{~m}$ (Fig. 4, Table 1). On the summit of the ShiHu micro-peninsula has sandy soil with marine mollusk shells (Glycimeris sp and Cerithium sp); however, because the shells are associated with ceramics, we interpret this deposit as archaeological in origin. Nevertheless, although no certain marine deposits are associated with these abrasion platforms, their marine origin is not doubtful, because paleo-stacks, honeycomb-weathering pits, marine tafonis and shallow tidal pools are encountered on them (see photos $C$ and D on Fig. 3).

\subsubsection{Haishan Island (Sequence B)}

Haishan Island, located on the northern coast of the Guangdong province near Nanao Island, is $9 \mathrm{~km}$ long and has a maximum width of $6 \mathrm{~km}$ (Fig. 6). It lies near a low coastal zone with intertidal mud flats that have been modified by human activities (see Bizhou area on Fig. 6). A sequence of marine terraces is present over a total distance of $3 \mathrm{~km}$ on the northeastern part of Haishan Island near Aobian village. Due to vegetation cover and human disturbance, the terraces are not continuously observable. This leads to difficulty in determining whether there are two or three terraces. Paleo-abrasion platforms are carved in intrusive granites, which are from lower and middle Mesozoic (Guangdong Geological Survey, 1965). Above a small modern abrasion platform, the lowest marine terrace is $25 \mathrm{~m}$ wide with a shoreline angle at $20 \pm 3 \mathrm{~m}$ above mean sea level (Fig. 6, Table 1). Above this terrace a 20-25 m wide flat morphology with a scarp at $28 \pm 3$ is observed, interpreted as a second terrace (Figs. $4 \mathrm{~B}$ and 6 ). Above this, the upper marine terrace, $60 \mathrm{~m}$ wide, has a shoreline angle at an elevation of $40 \pm 5 \mathrm{~m}$ (Figs. 4 and 6). No marine deposits associated with the Haishan terraces have been encountered but the marine origin of these morphologies is not doubted, because honeycomb weathering, marine tafoni, tidal pool and paleo-stacks are present on their surfaces. On the south margin of Haishan Island, a 7 m-thick deposit of sand and consolidated sand extends over a 2.8-km-long stretch of the coast and a maximum of $0.8-\mathrm{km}$ inland. These deposits have been described as beachrock and dated by Bi and Yuan (1988); however, the sediment does not conform with the established characters of beachrock (Purser, 1980), and is more appropriately interpreted as a shallow marine sand with many sea shells (coquina) from a wave-built terrace. The upper part of the deposit is associated with a notch at an elevation of $8 \pm 1 \mathrm{~m}$. Bivalves and gastropods for ${ }^{14} \mathrm{C}$-dating were collected from the inner edge of the deposit. The C14 sample gave a non-calibrated age of $2810 \pm 90 \mathrm{ky}$ (Table 2). Littoral deposits in Nanao Island and the Barto area are similar to the Haishan coquina. North of Buwei some low zones and/or wavebuilt deposits are observable (Fig. 5) on Landsat images (available at https://zulu.ssc.nasa.gov/mrsid/).

\subsubsection{Shanwei peninsula (Sequences $C, D$ )}

Along the $160 \mathrm{~km}$ coastline between Houmen and Guang'ao, littoral Holocene deposits and marine terraces record tectonic movement, identified by field and satellite observations (Fig. 7). To the northeast lies Lianjiang River, which is described as a half graben (Chen, 1995), which has two marine terrace sequences, from which were obtained preliminary dates of some Holocene coastal deposits in the western entrance of Shanwei City (Table 2).

Two marine terraces carved into Mesozoic granite (Guangdong Geological Survey, 1965) are found on the Shigonglia micro-peninsula. The lower (T1) terrace is $10 \mathrm{~m}$ maximum width and outcrops only on the westernmost point of Shigongliao micro-peninsula near the Buddhist temple. The T1 shoreline angle lies at an altitude of $12 \pm 4 \mathrm{~m}$ (Table 1). The margin of error is important because no clear shoreline angle is observable continuously in the landscape. The upper (T2) marine terrace marine develops extensively (Fig. 8A and B) and constitutes the top of the micro-peninsula. In some places this surface is eroded by fluvial and/or human erosion, resulting in the fact that no clear shoreline angle is observed but some paleo-islands and paleostacks are present (Fig. 8B). The main surface of this terrace stands at an elevation of 20-22 $\mathrm{m}$ and a maximal elevation of $25 \pm 3$ (Figs. 4 and $8 \mathrm{~A}$ ) $\mathrm{m}$ is interpreted here as the altitude of the shoreline angle of this marine terrace.

Table 2

${ }^{14} \mathrm{C}$ results (Geochemistry Laboratory of the Guangzhou University of Geography) on seashells from marine deposits of the northern coast of South China Sea

\begin{tabular}{|c|c|c|c|c|c|c|}
\hline Nom & Date & Location & Description & Observation & Age & Error range \\
\hline$\overline{\mathrm{LM}} 1$ & $6 / 26 / 2005$ & $22^{\circ} 47.283115^{\circ} 19.971^{\prime}$ & Seashells in bioclastic sand & Distal edge of the Holocene wave-built terrace & 1220 & 60 \\
\hline LM 2 & $7 / 5 / 2005$ & $23^{\circ} 31.272116^{\circ} 57.411$ & Seashells in bioclastic sandstone & Inner edge of the Holocene coastal deposit & 2810 & 90 \\
\hline
\end{tabular}




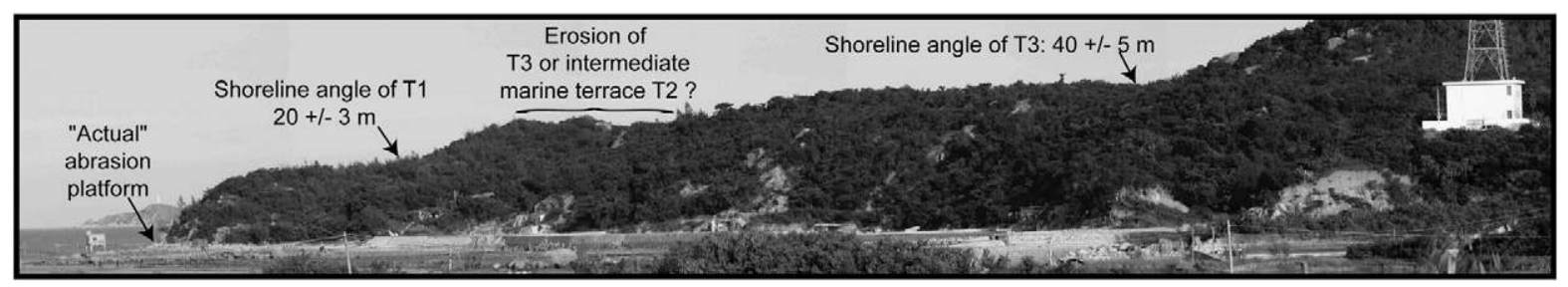

Fig. 7. View of the marine terrace (Sequence B) from the NE part of Haishan Island. Photo is taken looking to the south.

The top of the Zhelang micro-peninsula (Fig. 7) has a marine terrace carved in Mesozoic granites. However, this terrace lacks a clear shoreline. As the main surface is present at $18-20 \mathrm{~m}$, the shoreline angle would lies at $20 \pm 5 \mathrm{~m}$ (Table 1, Fig. 4); here the precision is influenced by human activity.

In the northwestern entrance of Shanwei City, at N $22^{\circ} 47.283^{\prime} \mathrm{E}$ $115^{\circ} 19.971^{\prime}$ a $2-\mathrm{m}$ sand deposit (Fig. 7) exposed by quarrying is present about $200 \mathrm{~m}$ inland from the beach and consists of 4 layers (Fig. 9). The lowest layer (A) consists in $0.8 \mathrm{~m}$ of grey whitish sand with nearly planes bed. In some parts the beds are coarser, with bioclasts and entire seashells; some of the latter have been sampled for carbon 14 analysis (Sample LM2 on Figs. 7 and 9). The second layer B consists of $40-\mathrm{cm}$ of gray whitish sand with low angle cross stratification. Few bioclasts are present in the beds. The third layer $C$ is a 45-cm gray whitish sand deposit with nearly planes bed. This layer is very similar to layer A but lacks marine shells. The fourth layer (D) consists of the same deposit as layer $C$ but its top is the outcrop upper limit, and the full thickness of layer $D$ is not preserved. The base of the outcrop lies at $3 \pm 1 \mathrm{~m}$ above mean sea level. This deposit extends about $700 \mathrm{~m}$ landward and constitutes a 13-km large wave-built terrace. We estimate its maximum altitude at $7 \pm 2 \mathrm{~m}$. The $\mathrm{C} 14$ sample gave an age of $1220 \pm 60 \mathrm{yr}$ (Table 2). This age must not be considered at representative of the wave-built terrace as 1) the sample was taken from the distal part of the terrace 2) the result is not calibrated, 3) sea shells can be reworked (sample not in life position).

\subsubsection{Western side of Hainan Island (Sequence E)}

The Hainan Island constitutes the biggest Chinese Island of the South China Sea. Marine terraces (some true abrasion platform but mostly wave-built terraces), beach ridges, coastal bars and notches sequences are present on the western and south part of the island along a $300 \mathrm{~km}$-long stretch of coast (Fig. 10). Hainan Island Quaternary coastal deposits and morphologies have been the subject of a brief description (in English) in a congress (Wang et al., 2000) and articles (in Chinese) about local Holocene relative sea level (Huang and Zhu, 1985), beachrocks (Wang, 1991a,b), Holocene carbonates (Lassen et al., 1995).

Wang et al. (2000) described remnants of pre-Pleistocene, highly indented shorelines occurring as terraces on the hills at different elevations ranging from $80 \mathrm{~m}$ to $40 \mathrm{~m}$. Lower, more recent terraces at 20,10 and $5 \mathrm{~m}$ asl record the development of the coast during Late Pleistocene and Holocene. In the coastal plains, best exposed in the Sanya region, there are up to eight to nine coastal bars, from small residual inland uplifted ones around promontories of hills to the recent extensive (approximately $10-15 \mathrm{~km}$ long and 5-600 $\mathrm{m}$ wide) more recent bars that occur along the present shore. The internal architecture of the more recent bars can be readily defined using Ground Penetrating Radar (GPR) (Wang et al., 2000). This shows that the bars have developed over bedrock, reefal platforms or beachrock. Their deeper horizons have characteristic lexeme-like GPR facies of shoreface to coastal sand, and their top parts are characterized by locally well-developed, stacked, seaward prograding 3-4 m thick cross beds. Where not stripped by human activities, aeolian dunes generally cap them. The total sand thickness of the bars reaches up to 8-10 m (Wang et al., 2000).

This preliminary study focused on the western point of Hainan Island, in the vicinity of the Dongfang town (Figs. 10 and 11). The strategy was to measure precise altitudes on the lowest shoreline angles. In the vicinity of Dongfang City we studied a $15 \mathrm{~km}$-long stretch of coast. We found a sequence of two notches in the port of

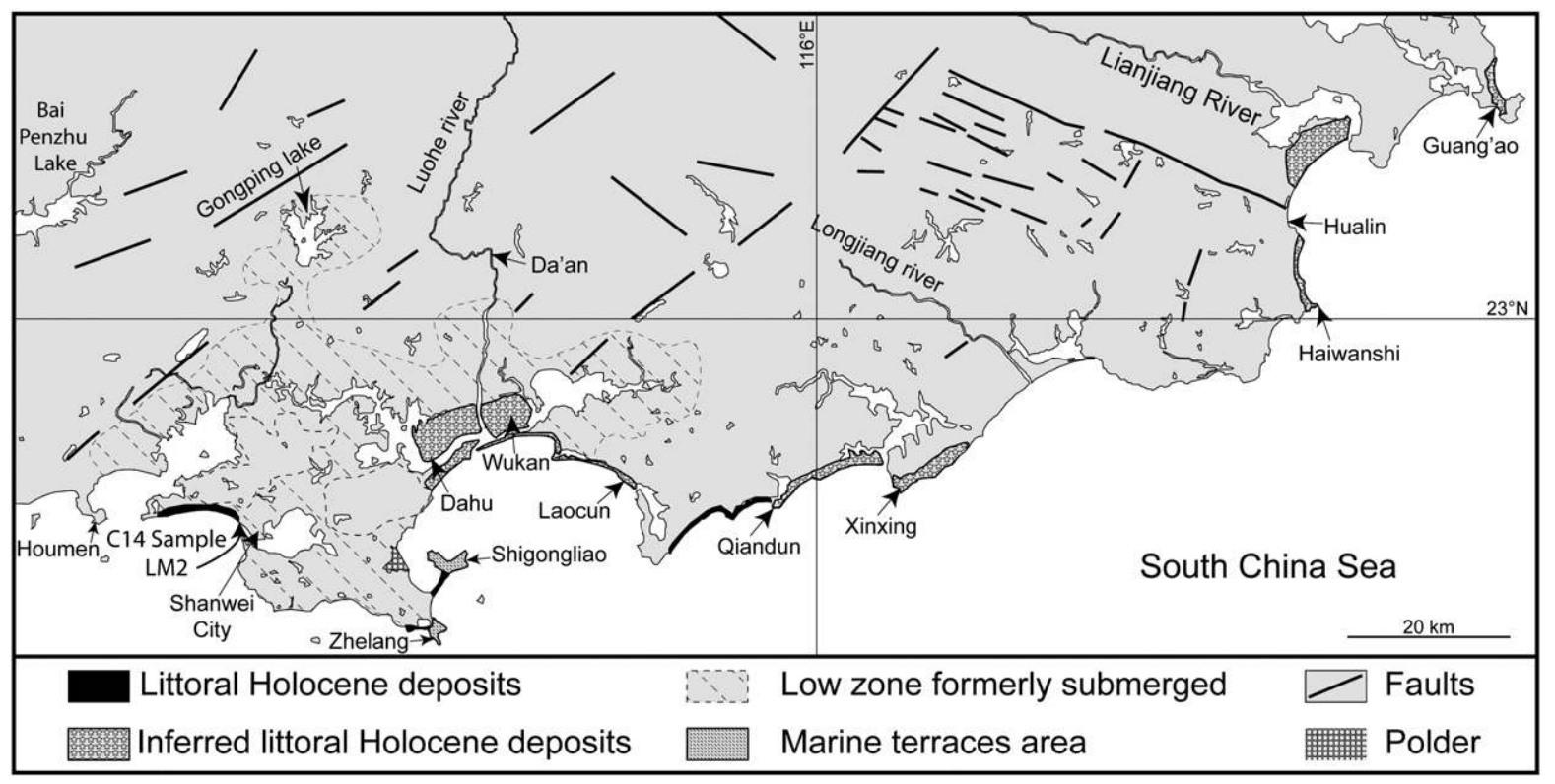

Fig. 8. Marine terraces (Sequence C, Shigongliao and D Zhelang) and Holocene littoral deposits between Houmen and Guang'Ao. 


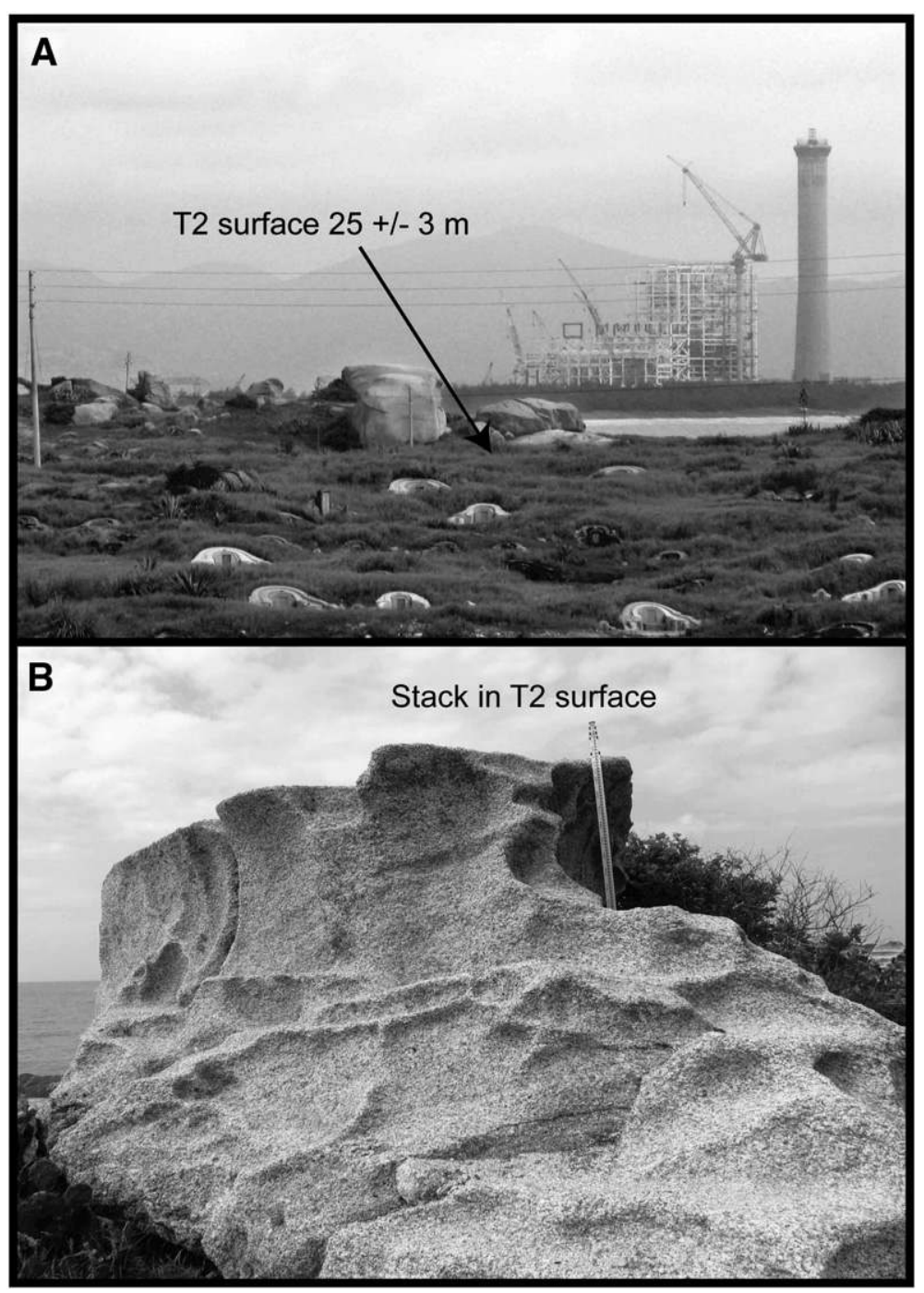

Fig. 9. View of the marine terrace (Sequence C) from Shigongliao (Shanwei vicinity). A) General view of T2. B) Morphology of a paleo-stack in T2 (altitude 18 m).

Dongfang town and the best location for marine terrace measurement is located between the village of Xinjie and the Si Ling mount (Fig. 11). In this zone the marine terrace extend at least $20 \mathrm{~km}$ inland but probably much more, up to the vicinity of the Wanglao village. On landsat images, it seems that a minimum of two other terraces with distinct shoreline angle are present (see dashed lines on Fig. 11).

Between the sea and Si Ling mount we studied a sequence of 2 marine terraces (Fig. 4) above the terrace (TH) previously described as Holocene (Guangdong Geological Survey, 1964; Wang et al., 2000). These marine terraces are evident in the landscape but are cultivated for watermelons resulting in partial destruction of their morphologies and deposits. Aelioan deposits also extensively cover these terraces. The Holocene terrace (TH) extends over $500 \mathrm{~m}$ (Fig. 12) with its shoreline at an altitude of $5 \pm 1 \mathrm{~m}$. T1 marine terrace extends over more than $1 \mathrm{~km}$ and its shoreline angle lies at an altitude of $11 \pm 2 \mathrm{~m}$. $\mathrm{T} 2$ terrace is wider than $\mathrm{T} 1$ and extends over nearly $2 \mathrm{~km}$ with a shoreline angle at an altitude of $22 \pm 4 \mathrm{~m}$.

To the west of Dongfang, in the port area is a sequence of two notches; the lowest has an associated paleo-abrasion platform. The notches are carved in the Mesozoic granites. The lowest notch is not well preserved due to human activity. Its altitude is measured at $5 \pm$ $2 \mathrm{~m}$ near a paleo sea-cave (which is used as a small temple). A fossil abrasion platform is probably associated with this notch, $2 \mathrm{~m}$ above the modern platform but it is nearly totally destroyed. Above this notch, the upper notch is present $10 \pm 3 \mathrm{~m}$ above mean sea level. The upper notch is present over tens of meters around the cape. The lowest notch is about $1 \mathrm{~m}$ high and from 0.5 to $1.5 \mathrm{~m}$ deep. The second notch is about $3 \mathrm{~m}$ high and 2-3 m deep. By comparison to the general morpho-stratigraphy of the western part of Hainan Island, we tentatively correlate the lowest notch with the Holocene marine terrace encountered to the north and probably to the south, based on: 1) the altitudinal and structural continuity between the notch and the Holocene marine terrace and 2) the fact that no fault is registered in this area. In this zone, we also tentatively correlate the upper notch with the T1 marine terrace for the reasons mentioned above.

\subsection{Chronostratigraphic interpretation and uplift rates}

\subsubsection{Middle and Late Pleistocene}

Following standard practice (Lajoie, 1986; Johnson and Libbey, 1997; Pedoja et al., 2006b), we generally correlated the lowest prominent marine terrace with MIS 5; and in order to get the minimum uplift rate, the shoreline of this terrace was correlated with the peak or maximum of this interglacial (MISS 5e), pending further work to demonstrate unequivocal deposits associated with this age. In most of the cases, the lowest prominent terrace is the one that we, during field works named T1, with exception of the Shigongliao micropeninsula and western Hainan Island (Sequences $C$ and $E$ respectively) where the lowest terrace is not correlated to MIS 5e (see further). 


\begin{tabular}{|c|c|c|c|}
\hline $2 \mathrm{~m}$ & 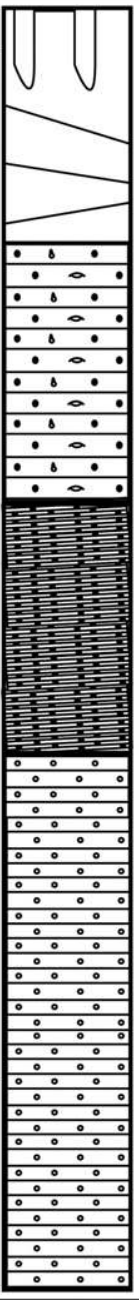 & $\begin{array}{r}1.20 \\
\text { B } \\
0.80\end{array}$ & $\begin{array}{l}\text { Same sand as } \\
\text { C but removed } \\
\text { by human } \\
\text { activity and } \\
\text { soil } \\
\text { Grey whitish } \\
\text { sand with } \\
\text { nearly planes } \\
\text { beds. } \\
\text { Grey whitish } \\
\text { sand with low } \\
\text { angle cross } \\
\text { stratification. } \\
\text { Few biocalst } \\
\text { Grey whitish } \\
\text { sand with } \\
\text { nearly planes } \\
\text { beds. } \\
\text { Sometime } \\
\text { beds of } \\
\text { coarser sand } \\
\text { with bioclast } \\
\text { and entire } \\
\text { seashells. } \\
\text { Sample LM } 2 .\end{array}$ \\
\hline
\end{tabular}

Fig. 10. Log section of sand deposit in the western entrance of Shanwei City (see Fig. 8 for location).

On the ShiHu micro-peninsula (Sequence A), calculated uplift rates for T1 range from 0.10 to $0.26 \mathrm{~mm} / \mathrm{yr}$ (Table 1 ) (or $0.18 \pm 0.08 \mathrm{~mm} / \mathrm{yr}$, Fig. 13A). If a constant uplift rate of $0.18 \mathrm{~mm} / \mathrm{yr}$ is extrapolated back in time, the $40 \pm 7 \mathrm{~m}$ elevation of $\mathrm{T} 2$ and the $60 \pm 10 \mathrm{~m}$ elevation of T3 would suggest that these terraces were formed between 183-261 ka (T2), and 277-388 ka (T3) (Fig. 13A). As a preliminary hypothesis we propose that T2 and T3 could be correlated with highstands associated to MIS 7 and 9 respectively. This extrapolation agrees with local morpho-stratigraphy (i.e. weak development of $\mathrm{T} 2$ compared to $\mathrm{T} 1$ or T3).

On the northeast part of the Haishan Island (Sequence B), calculated uplift rate for $\mathrm{T} 1$ ranges from 0.08 to $0.20 \mathrm{~mm} / \mathrm{yr}$ (Table 1) (mean of $0.14 \pm 0.06 \mathrm{~mm} / \mathrm{yr}$, Fig. 13B). If a constant mean uplift rate of $0.14 \mathrm{~mm} / \mathrm{yr}$ is extrapolated back in time, the $28 \pm 3 \mathrm{~m}$ elevation of T2 and the $40 \pm 5 \mathrm{~m}$ elevation of T3 would suggest that these terraces were formed between 178 and $221 \mathrm{ka}$ (T2) and $250 \mathrm{ka}$ and $321 \mathrm{ka}$ (T3) (Fig. 13B). Note that this interpretation is made under the constraint of uncertainty about whether $\mathrm{T} 2$ represents a separate terrace, which future work may resolve. Combining this extrapolation with the local morpho-stratigraphy (i.e. strong development of T1 and T3) we suggest, in any case, correlating T3 with MIS 9 (Fig. 13B). The T2 terrace if accepted as a terrace would not introduce any drastic change in the uplift velocity from T3 to T1 (see Table 1 and Fig. 13B for the resultant uplift rates). In our point of view, the apparent uplift reduction from T3 ( $0.14 \mathrm{~mm} / \mathrm{yr}$, MIS 9$)$ to T1 (0.10 mm/yr, MISS 5e) is not significant as the margins of errors are to be taken into account (Table 1).

On the Shigongliao micro-peninsula (Sequence C), we do not follow standard practice because T1 terrace $(12 \pm 4 \mathrm{~m})$ is not the prominent terrace in this zone. As a consequence of this local morphostratigraphy and comparing with nearby morpho-stratigraphy (Zhelang) T2 marine terrace is correlated with MISS 5e. Uplift rates for T2 ranges from 0.10 to $0.26 \mathrm{~mm} / \mathrm{yr}$ (Table 1) $(0.18 \pm 0.08 \mathrm{~mm} / \mathrm{yr})$. T1 marine terrace could be a 1) human artefact, 2) Holocene terrace 3) a small platform associated with a highstand posterior to MISS 5e (i.e. MISS 5a or MISS 5c). Further studies are necessary in this zone in order to better decipher the coastal morphology.

On the Zhelang micro-peninsula (Sequence D) calculated uplift rate for T1 ranges from 0.08 to $0.22 \mathrm{~mm} / \mathrm{yr}$ (Table 1 ) (or $0.15 \pm 0.07 \mathrm{~mm} / \mathrm{yr}$ ). It seems probable that the nearby Shigongliao and Zhelang micropeninsula of experienced the same uplift velocities $(0.18 \pm 0.08$ and $0.15 \pm 0.07$, Table 1) during late Pleistocene as no fault is known on the geologic map of the zone nor have been observed on satellite image.

On the western part of Hainan Island (Sequence E), the lowest marine terrace $(5 \pm 4 \mathrm{~m})$ which is not the prominent terrace in this zone, has been interpreted as Holocene (Wang et al., 2000). As a consequence of the local morpho-stratigraphy we named this terrace $\mathrm{TH}$ and correlate the prominent T1 marine terrace $(11 \pm 2)$ with MISS $5 e$ in the absence of datable remains. Calculated uplift rates for T1 range from 0.02 to $0.11 \mathrm{~mm} / \mathrm{yr}$ (Table 1 ) (or $0.07 \pm 0.05 \mathrm{~mm} / \mathrm{yr}$ ). For the formation of T2 terrace, there are two hypotheses to identify the appropriate MIS (Table 1). The first hypothesis correlates T2 with MIS 7 (penultimate interglacial, $220 \mathrm{ka}$, "weaker" than MISS 5e). The second hypothesis correlates T2 with MIS 9 ("strong" interglacial, $\sim 330 \mathrm{ka}$ ). For the transect where T2 was measured (Sequence E), the latter hypothesis (T2=MIS 9) produces more uniform uplift rates (Table 1). This result is as expected, because MIS 7 was weaker than MIS 5 or 9 , and its terraces are typically only preserved where uplift rates are more rapid (Zazo, 1999); these interpretations will require corroboration with datable evidence which was not found in this study.

\subsection{Holocene}

On the northern coast of the South China Sea, wave-built deposits and Holocene morphologies are found at altitudes that do not necessarily imply important tectonic movements. As stated above, we interpret mid-Holocene highstands at $4 \pm 1$ and $1.5 \pm 1 \mathrm{~m}$. The Haishan and Shanwei Holocene wave-built terrace are found at $8 \pm 1$ and $7 \pm 2 \mathrm{~m}$ respectively, could be correlated with the maximum $5 \mathrm{~m}$ higher than present Holocene highstand. As an element of comparison, we extrapolate Late Pleistocene uplift rates from the nearest marine terrace sequence. In Haishan, an extrapolation of the MISS 5e uplift rate from Sequence B ( 0.08 to $0.20 \mathrm{~mm} / \mathrm{yr}$ or $\mathrm{m} / \mathrm{ka}$ ) would imply 0.40 to $1 \mathrm{~m}$ vertical displacement for the last $5000 \mathrm{yr}$. In Shanwei an extrapolation of the MISS 5e uplift rate would lead to a $0.50-1.30 \mathrm{~m}$ range for the last $5000 \mathrm{yr}$. These displacements combined 1) with the assumed $4 \pm 1 \mathrm{~m}$ mid-Holocene highstand and 2) with lithological factors that tends to produce rough shoreline angles (unlike limestones, which preserve notches more effectively), could explain the present elevation of this Holocene wave-built terrace.

\section{Discussion}

Abrasion platforms carved into granites are expected to be problematic to interpret; in contrast, limestones produce reliably recognisable submarine abrasion platforms particularly if the inner margin is identifiable using fixed biological indicators. However, the terraces observed in this study were cut into granite to produce flat surfaces that 


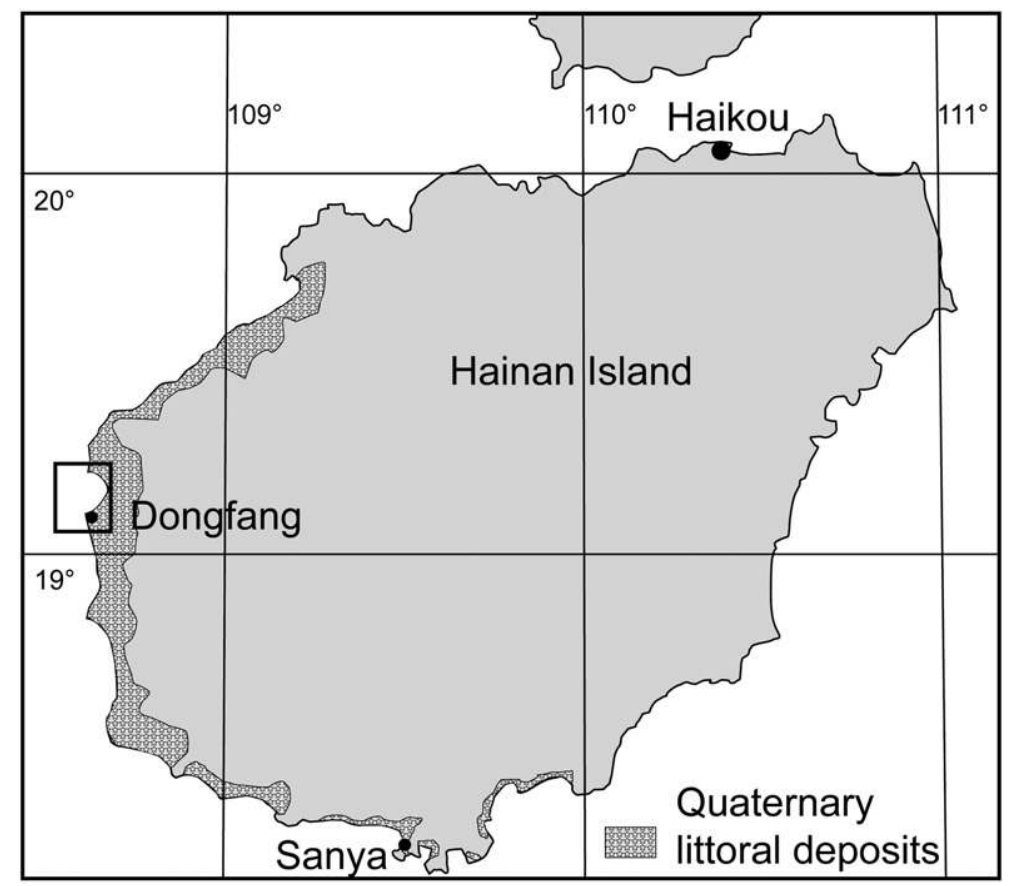

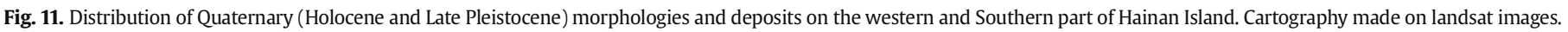

terminate seawards in small downsloping cliffs, and landwards in upsloping cliffs. Examination of close-up photos in Figs. 3C, D and 8B show approximately horizontal layering in the granite. It is possible that weathering and erosion of granites could lead to such morphologies in the absence of coastal effects; but the fact that these terraces occur in coastal locations (and not inland), and that they can be approximately correlated in terms of height, are good indicators that they are actually marine terraces. We therefore consider them as marine terraces for this assessment.

Prior to confirmation of radiometric ages of the geomorphology and sediments along the south China coastline, this preliminary study develops the most appropriate chronostratigraphical hypothesis to determinate the Middle and Late Pleistocene coastal mean uplift rates on the northern South China Sea. Resulting net uplift rates calculated for MIS 5, 7, 9, (Fig. 14) do not give evidence of significant change of uplift rates through time: variations are not representative of any tendency with respect to the margin of errors (Fig. 14, Table 1). Thus, uplift rate variations along the Chinese coast can be analyzed relatively to MISS $5 \mathrm{e}$, which is the most recent interglacial and the best constrained with respect to chrono-stratigraphy. Taking into account the margins of errors, the MISS 5e uplift rate range between $0.02 \mathrm{~mm} / \mathrm{yr}$ (Sequence E) and $0.26 \mathrm{~mm} / \mathrm{yr}$ (Sequence A) (Fig. 10).

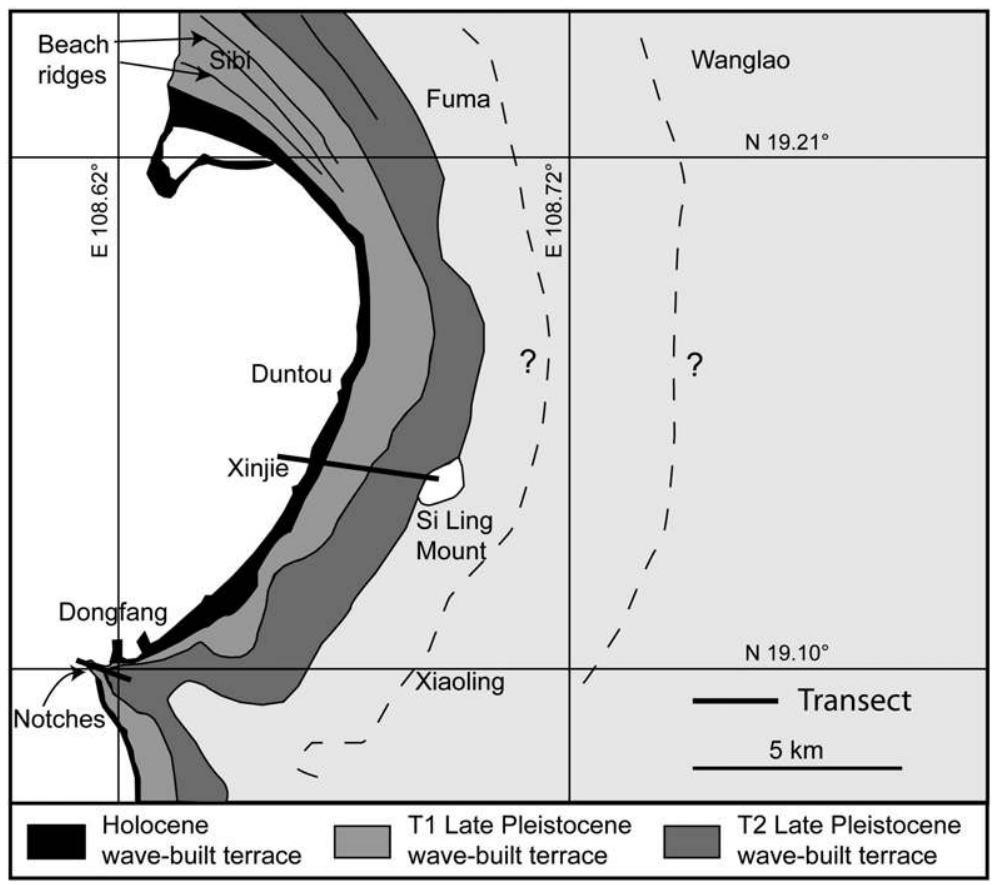

Fig. 12. Distribution of Late Quaternary notches and wave-built terraces (Sequence E) in the area of Dongfang City, western part of Hainan Island. 


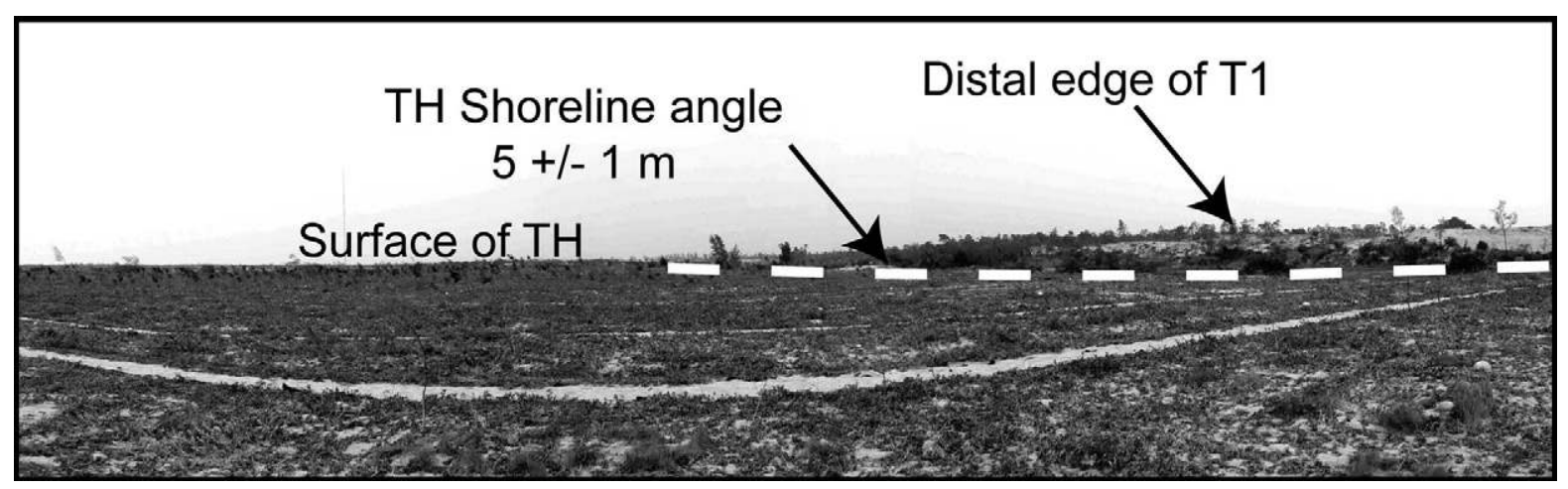

Fig. 13. View of the Holocene wave-built terrace (TH) and its shoreline angle near Xinjie village (western part of Hainan Island).

In order to investigate the characters of the South China coastal uplift, comparisons may be made with other passive margins worldwide; five have been chosen because their regional scale that is similar to the South China area, and outlined as follows. 1) On the northeastern coast of Brazil, the MIS 5e terrace lies at altitude generally ranging between 1 and $10 \mathrm{~m}$ and with a maximum of $20 \mathrm{~m}$ (Magnolia et al., 2002); also there is considerable similarity between the Holocene sea-level curve of Brazil and the South China Sea areas (Baker et al., 2003). Following our practice to calculate uplift rates, these altitudes lead us to propose rate of vertical deformation ranging from 0.12 to $0.20 \mathrm{~mm} / \mathrm{yr}$. The authors analyze their data as consistent with a scenario in which northeastern Brazil has been subjected to differential subsidence or uplift motions in late Quaternary. These vertical motions could be related to the local tectonic setting of Cretaceous fault-bounded structural blocks, some of them having been active in the Quaternary. 2) On the passive margin of Argentinean Patagonia, Rostami et al. (2000) determined, through the study of marine terraces sequence, a mean uplift rate of $0.09 \mathrm{~mm} / \mathrm{yr}$ since the Middle Pleistocene. The Last Interglacial Maximum terraces (MISS 5e) are found at altitude of 16-17 m along a 1000-km-long stretch of coast. For these authors, it is probably the proximity to the subduction zone of western South American that is responsible for the tectonic uplift of Patagonian Argentina. 3) On the western coast of Africa, in Mauritania and Senegal, very small uplift is registered through some Late Pleistocene marine deposits and morphologies (Giresse et al., 2000). The MIS 5 coastal deposits are found at maximum altitudes of 6 to $10 \mathrm{~m}$. Taking into account our methodology to determine uplift rates, this would imply maximum uplift rate ranges from 0.02 to $0.08 \mathrm{~mm} / \mathrm{yr}$. (Giresse et al., 2000) consider that no uplift occurred on the West African passive margin. 4) On the passive margin of India, precisely on the southeastern coast, Banerjee (2000) described a sequence of marine terraces, carved on and locally blanketed by Late Pleistocene biotic and terrigenous accumulations, and occurring up to $4.9 \mathrm{~m}$ above High Tide Level. Banerjee (2000) interpreted these terraces to signify discrete stillstand episodes followed by abrupt intervals of rising/falling sea level rather than tectonic movements. 5) Bryant (1992) made a recompilation of data about sea-level trends in Australia. The data from the last interglacial period indicates that the southern part of the Island experienced a 5-m uplift. New South Wales and Western Australia remain stable with the noticeable exception of the west side of Cape Range where a coralline terrace associated with MISS 5e was found at a maximum elevation of $18 \mathrm{~m}$ (Van de Graaf et al., 1976); this gives uplift rates ranging from 0.08 to $0.15 \mathrm{~mm} / \mathrm{yr}$. For these authors, uplift is related to faulted blocks. At a global scale, passive margin appears to be subjected to uplift as well as subsidence separated by hinge lines (see coast of Eastern South America, Rostami et al., 2000) with a relatively weak or even no uplift during Middle and Late Quaternary (West Africa, South India).
On the northern coast of the South China sea, the pattern of deformation is similar to other places: patches of uplifted coastal segments are separated by subsiding areas which are the location of few large rivers such as the Pearl River or the Lianjiang River northeast of Shanwei. Compared to other passive margins the most striking characteristics of the Late Pleistocene uplift of the northern coast of South China is its intensity over a large distance: 0.1 to $0.2 \mathrm{~mm} / \mathrm{yr}$ over $1200 \mathrm{~km})$.

The geographical homogeneity must be discussed herein because our preliminary results consist in mean uplift rates for only 4 places on the South China Sea Coast of China. In particular, our study does not include the southwest Guangdong and Guangxi coasts, implying a $400 \mathrm{~km}$ long data gap on which further studies must focus. In any case, satellite image and map analysis and Chinese literature reveals the occurrence of Middle and Late Pleistocene morphologies on the Bailong peninsula in Xiniujiao, Tieshan Harbor and Weizhou Island (Collective, 1969). In any case, as the occurrence of marine terrace flights reveals, itself, coastal active tectonics, we interpret that the northern coast of the South China Sea from Hainan to southern Fujian is experiencing Middle and Late Pleistocene coastal uplift marked on peninsulas. Thus in term of geographical extension the South China Coast uplift can only be compared to the Patagonian uplift in eastern South America, which following Rostami et al. (2000) is 1) slightly weaker and 2) result from a regional parameter; i.e. to the subduction of the Pacific plates under Western South America.

One major source of questioning comes from the fact that that uplifts are very similar even if the flights are not in the same regional geodynamical context. For example, Southern Fujian coast contains the back arc of an active plate boundary, while Hainan Island zone can be considered as strike-slip passive margin (Wei and Chung, 1995) and eastern Guangdong a faulted passive margin. But, the intensity of deformation appears to be very similar. Furthermore the Fujian Province of China belongs to the foreland of the collision zone where the encroachment of the Luzon arc on the continental margin of China took place. Consequently, subsidence should be suspected because of the flexure of the continental crust due to the load of the Luzon arc.

Furthermore, when compared to similar case of coastal vertical deformation, uplift rates from the northern coast of South China Sea are globally slightly higher. Why? Is there a geodynamical factor producing a convergence in this zone? At this point, it must be pointed out that we do not know if rates can be considered for longer period of time (what could help to prove a large-scale origin?). No Pliocene littoral deformed strata are described inland. Is this uplift continuous through time? For how long does it last? What is the real accuracy of the Late Quaternary uplift when compared to longer geological times?

We need to compare our uplift rates with the Holocene uplift rate and the modern sea-level relative change. 


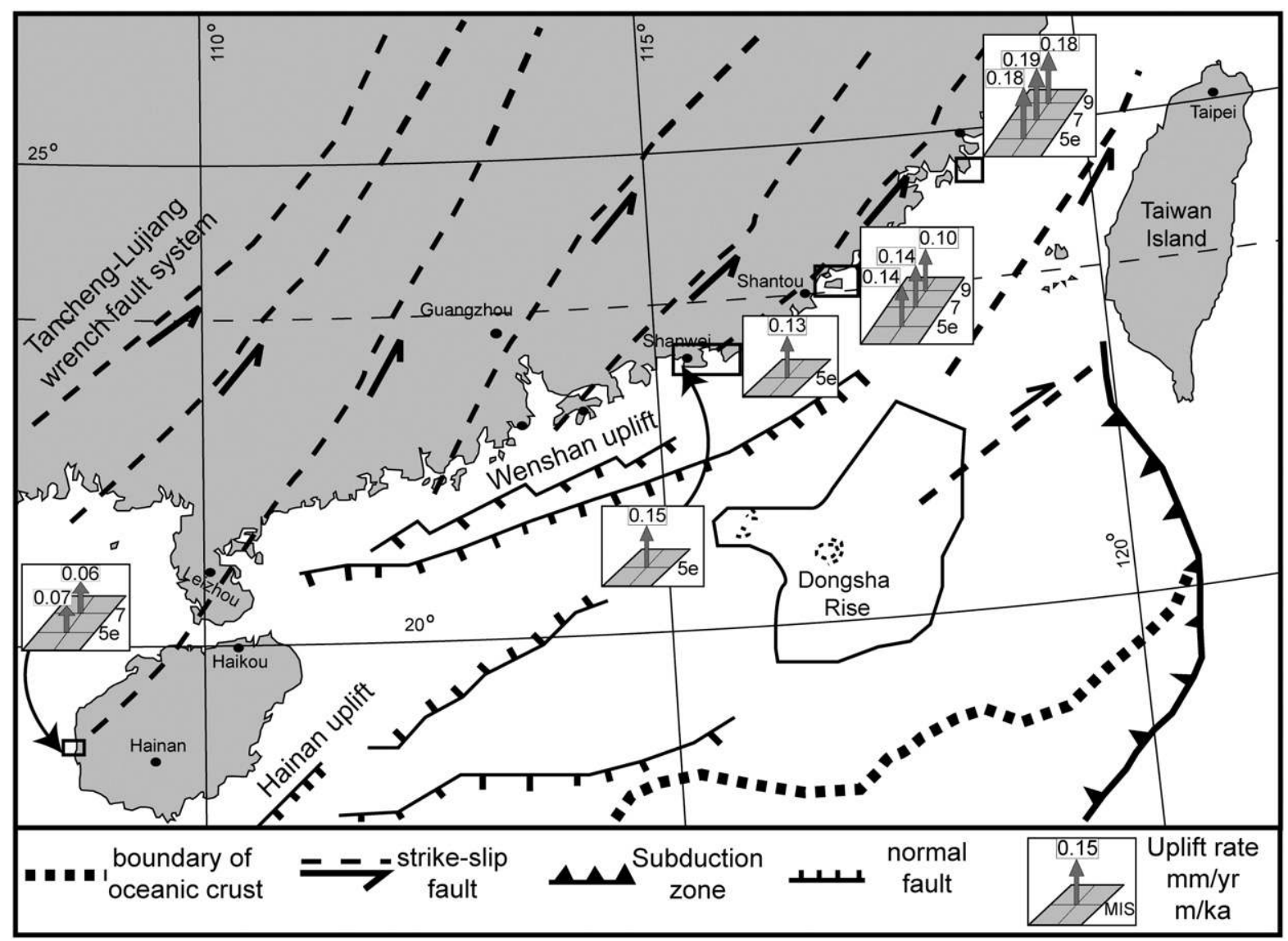

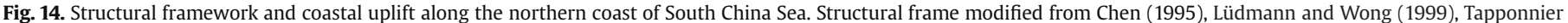
et al. (1986), Zhang et al. (2003)

Huang and Zhang (2005) published a recompilation of ${ }^{14} \mathrm{C}$ data available for coastal Holocene morphologies and deposits from the South China Sea coast. According to them, the west coast of Guangdong province, the south and southwest coast of Hainan Island are experiencing uplift of 1.0-1.5 mm/a, 1-2 mm/an and 0-1 mm/an. Relative sea-level change has been studied mainly by tide-gauge analysis (Emery and Aubrey, 1986; Huang and Zhang 2004). For these authors, rates of these relative changes, and more particularly the coastal uplift are estimated to be as high as $5 \mathrm{~mm} / \mathrm{yr}$ and are frequently of 1 to $2 \mathrm{~mm} / \mathrm{yr}$. Emery and Aubrey (1986) described this low-frequency positive vertical movements in the areas of massifs and ancient foldbelts. In area of Cenozoic basins, the subsidence can be up to $9 \mathrm{~mm} / \mathrm{yr}$. Although the tide-gauge records are sparse, inferences from them are supported by the stratigraphy and structures of the region and by raised marine terraces (described in this paper). This discrepancy between Holocene and/or actual uplift rates and Late Pleistocene one has been described all around the Pacific rim (Ota and Yamaguchi, 2004) but is still not perfectly understood.

The Chinese marine terrace flights raise more questions than they answer. Why are Fujian and northern Fujian uplifting although they are in a back arc position? Do different regional contexts tend to result in uniform uplift rates? Or is there a large-scale factor influencing the uplift? At this stage of knowledge, Middle and Late Pleistocene coastal positive vertical deformation are extensively present on the South China cast but, due to the lack of data about precise geodynamical context, the origin of active tectonics on segment of coast be assessed only by suggestion. In particular, a large-scale phenomenon (denudation process, bulge due to the IndoAsian collision) can be suspected (Huang and Zhang, 2004, this study) but is not proved.

\section{Conclusions}

The coast of the northern South China Sea is uplifted along a passive margin. Taking into account margins of error, late Quaternary uplift rates range from $0.02 \mathrm{~mm} / \mathrm{yr}$ up to a maximum of $0.26 \mathrm{~mm} / \mathrm{yr}$. The means for the last $\sim 125 \mathrm{ka}$ range from 0.07 to $0.18 \mathrm{~mm} / \mathrm{yr}$. Compared to other example of Quaternary coastal uplift along passive margin, the main uplift registered along the northern coast of the South China Sea is higher. The uplift rates quantified in this study can be used to correct any Holocene sea-level curve for this far-field location. Such studies of Pleistocene coastal evolution and active tectonics will improve the understanding of other deforming passive margins.

\section{Acknowledgments}

This work was supported by 1) CAS (The Chinese Academy of Sciences) Hundred Talents Program, 2) funding from Key Laboratory of Marginal Sea Geology, South China Sea Institute of Oceanology (MSGL0601). This study participates in the IGCP 495 "Quaternary Land-Ocean Interaction".

\section{References}

Baker, R.G.V., et al., 2003. Comment on "Mid-Holocene higher sea level indicators from the south China coast" by W.W.-S Yim and G. Huang [Mar. Geol. 182 (2002) 225-230]: a regional perspective. Mar. Geol. 196, 91-98.

Baker, R.G.V., Haworth, R.J., Flood, P.G., 2001. Inter-tidal fixed indicators of former Holocene sea levels in Australia: a summary of sites and a review of methods and models. Quat. Int. 83-85, 257-273.

Banerjee, P.K., 2000. Holocene and Late Pleistocene relative sea level fluctuations along the east coast of India. Marine Geology 167 (3-4), 243-260. 
Beaman, R., Larcombe, P., Carter, R.M., 1994. New evidence for the Holocene sea-level high from the inner shelf, central Great Barrier Reef, Australia. J. Sediment. Res. A64 (4), 881-885.

Bi, F., Yuan, Y., 1988. Study on the "beachrock field" in Haishan Island, Guangdong Province. Chinese Journal of Oceanology and Limnology 6 (4), 343-357.

Bryant, E., 1992. Late interglacial and Holocene trends in sea-level maxima around Australia: implications for modern rates. Mar. Geol. 108, 209-217.

Bull, W.B., 1985. Correlation of flights of global marine terraces. In: Morisawa, M., Hack, J. (Eds.), 15th Annual Geomorphology Symposium. State University of New York at Binghampton, Hemel Hempstead, pp. 129-152.

Carter, R.M.G., Woodroffe, C.D., 1994. Coastal Evolution: Late Quaternary Shoreline Morphodynamics. Cambridge University Press, Cambridge. 517 pp.

Chappell, J., 1974. Geology of coral terraces, Huon Peninsula, New Guinea: a study of Quaternary tectonic movements and sea level changes. Geol. Soc. Amer. Bull. 85, 553-570.

Chen, W., 1995. The Neotectonic Map of Guangdong Province. In: T.S.A.o.G. Province (Ed.), Guangdong Seismological Bureau Guangzhou (in Chinese).

Chen, Y.-G., Liu, T.-K., 1996. Sea level changes in the last several thousand years, Penghu Islands, Taiwan Strait. Quat. Res. 45 (3), 254.

Chen, Y.-G., Liu, T.-K., 2000. Holocene uplift and subsidence along an active tectonic margin southwestern Taiwan. Quat. Sci. Rev. 19 (9), 923.

Chen, Y.-G., Liu, J.C.L., Shieh, Y.-N., Liu, T.-K., 2004. Late Pleistocene to Holocene environmental changes as recorded in the sulfur geochemistry of coastal plain sediments, southwestern Taiwan. J. Asian Earth Sci. 24 (2), 213.

Collective, 1969. Coastal zone and tidal marsh of the Guangxi Autonomous Region. Geomorphol. Quat. Geol. 6.

Davis, A.M., 1999. Quaternary stratigraphy of Hong Kong coastal sediments. J. Asian Earth Sci. 17, 521-531.

Davis, A.M., et al., 2000. Late Holocene higher sea-level indicators from the South China coast. Mar. Geol. 171, 1-5

Emery, K.O., Aubrey, D.G., 1986. Relative sea-level changes from tide-gauge records of Eastern Asia mainland. Mar. Geol. 72, 33-45.

Fyfe, J.A., Shaw, R., Campbell, S.D.G., Lai, K.W., Kirk, P.A., 2000. The Quaternary Geology of Hong Kong. Geotechnical Engineering Office, Civil Engineering Department, The Government of the Hong Kong Special Administrative Region, Hong Kong. 209 pp.

Giresse, P., J.-P., B., Causse, C., Diouf, B., 2000. Successions of sea-level changes during the Pleistocene in Mauritania and Senegal distinguished by sedimentary facies study and U/Th dating. Mar. Geol. 170, 123-139.

Hearty, P.J., Kindler, P., 1995. Sea-level highstand chronology from stable carbonate platforms (Bermuda and the Bahamas). J. Coast. Res. 11 (3), 675-689.

Herbert Veeh, H., 1966. $\mathrm{Th}^{230} / \mathrm{U}^{238}$ and $\mathrm{U}^{234} / \mathrm{U}^{238}$ Ages of Pleistocene high sea level stand. J. Geophys. Res. 71 (14), 3379-3386.

Hori, K., et al., 2004. Delta initiation and Holocene sea-level change: example from the Song Hong (Red River) delta, Vietnam. Sediment. Geol. 164, 237-249.

Hsieh, M.-L., Liew, P.-M., Hsu, M.-Y., 2004. Holocene tectonic uplift on the Hua-tung coast, eastern Taiwan. Quat. Int. 115-116, 47.

Huang, J., Zhu, Z., 1985. Tombolo development and sea level changes in Luhuitou of the Sanya city. Hainan Island International Geological Correlation Programme Project number 200 China working group. China Ocean Press, Beijing.

Huang, Z., Li, P., Zhang, Z., Zong, Y., 1986. Changes of sea level in south China coast since the late Pleistocene. In: I.C.w. group (Editor), China Sea-level Changes. China Ocean Press, Beijing, pp. 178-194.

Huang, Z.-G., Zhang, W.-Q., 2004. Advance of research on recent sea level changes in South China Sea. J. Oceanogr. Taiwan Strait 23 (4), 530-535.

Huang, Z.-G., Zhang, W.-Q., 2005. On elevation differentiation of the Holocene high sea level relics in the South China Sea area. J. Oceanogr. Taiwan Strait 24 ((2), $228-235$.

Imbrie, J., et al., 1984. The orbital theory of Pleistocene climate: support from revised chronology of the marine ${ }^{18} \mathrm{O}$ record. In: Berger, A., Imbrie, J., Hays, J.D., Kukla, G., Saltzman, B. (Eds.), Milankovitch and Climate. Dordrecht, Reidel, pp. 269-305.

James, N.P., Mountjoy, E.W., Omura, A., 1971. An early Wisconsin reef Terrace at Barbados, West Indies, and its climatic implications. Geol. Soc. Amer. Bull. 82, 2011-2018.

Johnson, M.E., Libbey, L.K., 1997. Global review of Upper Pleistocene (Substage 5e) rocky shores: tectonic segregation, substrate variation and biological diversity. J. Coast. Res. 13 (2), 297-307.

Jouannic, C., Hoang, C.T., Hantoro, W.S., Delinom, R.M., 1988. Uplift rate of coral reef terraces in the area of Kupang, West Timor: preliminary results. Palaeogeogr. Palaeoclimatol., Palaeoecol. 68, 259-272.

Kershaw, S., Guo, L., 2001. Marine notches in coastal cliffs: indicators of relative sealevel change, Perachora Peninsula, central Greece. Mar. Geol. 179, 213-228.

Kim, J.-Y., Lee, Y.-J., 2006. La stratigraphie du Pléistocène supérieur et le Paléolithique en Corée. L'anthropologie 110, 119-138.

Kukla, G.J., et al., 2002. Last interglacial climates. Quat. Res. 58, 2-13.

Lajoie, K.R., 1986. Coastal tectonics. In: Press, N.A. (Ed.), Active tectonics. National Academic Press, Washington DC, pp. 95-124.

Lam, D.D., Boyd, W.E., 2003. Holocene coastal stratigraphy and the sedimentary development of the Hai Phong Area of the Bac Bo Plain (Red River Delta), Vietnam. Aust. Geogr. 34 (2), 177-194.

Lassen, M., Schneider, W., Geng, A., Liu, X., 1995. Sedimentary and diagenesis of the Holocene Carbonate in Hainan Dao. Journal of Mineralogy and Petrology 15 (1), 50-57 (In Chinese with English abstract).

Lau, M., 2005. Integrated coastal zone management in the People's Republic of Chinaan assessment of structural impacts on decision-making processes. Ocean Coast. Manag. 48, 115-159.

Liew, P.-M., Hsieh, M.-L., Lai, C.-K., 1990. Tectonic significance of Holocene marine terraces in the Coastal Range, Eastern Taiwan. Tectonophysics 183 (1-4), 121-127.
Liew, P.M., Hsieh, M.L., 2000. Late Holocene (2 ka) sea level, river discharge and climate interrelationship in the Taiwan region. J. Asian Earth Sci. 18 (4), 499.

Liew, P.M., Hsieh, M.L., Shyu, B.H., 2004. An overview of coastal development in a Young Mountain Belt-Taiwan. Quat. Int. 115-116, 39.

Liew, P.M., et al., 1993. Holocene tectonic uplift deduced from elevated shorelines, eastern Coastal Range of Taiwan. Tectonophysics 222 (1), 55.

Lowe, J.J., Walker, M.J.C., 1997. Reconstructing Quaternary Environments, 2nd Edition. Longman, Harlow, U.K., 446 pp.

Lüdmann, T., Wong, H.K., 1999. Neotectonic regime on the passive continental margin of the northern South China sea. Tectonophysics 311, 113-138.

Lüdmann, T., Wong, H.K., Wang, P., 2001. Plio-Quaternary sedimentation processes an neotectonics of the northern continental margin of the South China Sea. Mar. Geol. $171,331-358$.

Magnolia, A., et al., 2002. Late Pleistocene marine terrace deposits in northeastern Brazil: sea-level change and tectonic implications. Palaeogeogr., Palaeoclimatol. Palaeoecol. 179, 57-69.

Morley, C.K., 2002. A tectonic model for the Tertiary evolution of strike-slip faults and rift basins in SE Asia. Tectonophysics 347, 189-215.

Morton, B., Blackmore, G., 2001. South China Sea. Mar. Pollut. Bull. 42 (12), 1236.

Muhs, D.R., 2002. Evidence for the timing and duration of the last interglacial period from high-precision uranium-series ages of corals on tectonically stable coastlines. Quat. Res. 58, 36-40.

Muhs, D.R., et al., 1990. Age estimates and uplift rates for late Pleistocene marine terraces: Southern Oregon portion of the Cascadia Forearc. J. Geophys. Res. 95 (B5), 6685-6688.

Ota, Y., 1986. Marine terraces as reference surfaces in late Quaternary tectonics studies: examples from the Pacific Rim. R. Soc. N. Z. 24, 357-375.

Ota, Y., Yamaguchi, M., 2004. Holocene coastal uplift in the western Pacific Rim in the context of late Quaternary uplift. Quat. Int. 120, 105-117.

Owen, R.B., 1995. Hong Kong landform series No 1shore platforms-characteristics and origins. Hong Kong Geol. 1, 43-45.

Pedoja, K., Bourgeois, J., Pinegina, T., Higman, B., 2006a. Does Kamchatka belong to North America? An extruding Okhotsk block suggested by coastal neotectonics of the Ozernoi Peninsula, Kamchatka, Russia. Geology 34 (5), 353-356.

Pedoja, K., Dumont, J.-F., Lamothe, M., Ortlieb, L., Collot, J.-Y., Ghaleb, B., Auclair, M. Alvarez, V., Labrousse, B., 2006b. Quaternary uplift of the Manta Peninsula and La Plata Island and the subduction of the Carnegie Ridge, central coast of Ecuador. South-Am. J. Earth Sci. 22, 1-21.

Pedoja, K., Ortlieb, L., Dumont, J.-F., Lamothe, J.-F., Ghaleb, B., Auclair, M., Labrousse, B., 2006c. Quaternary coastal uplift along the Talara Arc (Ecuador, Northern Peru) from new marine terrace data. Mar. Geol. 228, 73-91.

Pirazzoli, P.A., 1991. World Atlas of Holocene Sea-Level Changes. Elsevier, Amsterdam. 300 pp.

Pirazzoli, P.A., 1993. Global sea-level changes and their measurement. Glob. Planet. Change 8 (3), 135

Purser, B.H., 1980. Sédimentation et diagenèse des carbonates néritiques récents, 1 Technip, Paris. 367 pp.

Rostami, K., Peltier, W.R., Mangini, A., 2000. Quaternary marine terraces, sea-level changes and uplift history of Patagonia, Argentina: comparisons with predictions of the ICE-4G (VM2) model for the global process of glacial isostatic adjustment. Quet. Sci. Rev. 19, 1495-1525.

Rust, D., Kershaw, S., 2000. Holocene tectonic uplift patterns in northeastern Sicily: evidence from marine notches in coastal outcrops. Mar. Geol. 167, 105-126.

Shi, Z., Chen, J.Y., 1996. Morphodynamics and sediment dynamics on intertidal mudflats in China (1961-1994). Cont. Shelf Res. 16 (15), 1909.

Sibuet, J.-C., Hsu, S.-K., 2004. How was Taiwan created? Tectonophysics 379, 159-181.

Song, S.-R., Liu, C.-M., Chen, C.-H., Lo, W., 2004. Pumice layers in marine terraces: implications for tectonic uplift rates on the east and northeast coasts of Taiwan over the last hundreds of years. Quat. Int. 115-116, 83.

Tanabe, S., et al., 2003. Song Hong (Red River) delta evolution related to millenniumscale Holocene sea-level changes. Quat. Sci. Rev. 22 (21-22), 2345.

Tapponnier, P., Peltzer, G., Armijo, R., 1986. On the mechanics of the collision between India and Asia. In: Ramsay, J.G., Coward, M.P., Ries, A. (Eds.), Collision Tectonics. Special Publication Geological Society London, pp. 115-117.

Van de Graaf, W.J.E., Denman, P.D., Hocking, R.M., 1976. Emerged Pleistocene marine terrace on Cape Range, Western Australia Western Australia. Geological survey Annual Report 1975 62-70.

Wang, J., 1991a. Characteristics of the beachrocks in Tianya-Haijia and Yinggehai, Hainan Island and their depositional diagenetic environments. Tropic Oceanology 10 (4), 9-15 (In Chinese with English abstract).

Wang, J., 1991b. Some Beachrocks Discovered along the northwest coast of Hainan Island and their significances Acta Scientiarum Naturalium Universitatis Sunyatsenir 31 (1), 99-108.

Wang, Y., Martini, P., Zhu, D., Tang, W., Zhang, Y., 2000. Coastal plain evolution indicated by sandy barrier system in southern Hainan Island, China. In: Zhu, Y.W.A.X. (Ed.) IAG 2000 Monsoon Climate, Geomorphologic Processes and Human Activities International Conference Hotel of Nanjing, China.

Wei, B.Z., Chung, W.Y., 1995. Strike-slip faulting on the northern margin of the South China Sea: evidence from two earthquakes offshore of Hainan Island, China, in December 1969. Tectonophysics 241, 55-66.

Woodroffe, C.D., 2003. Coasts Form Process and Evolution. Cambridge University Press, Cambridge. $623 \mathrm{pp}$

Woodroffe, S.A., Horton, B.P., 2005. Holocene sea-level changes in the Indo-Pacific. J. Asian Earth Sci. 25 (1), 29.

Wu, Z., Wang, W., 1985. The characteristic and the development of dune rocks on South China coasts. International Geological Correlation Programme Project number 200 China working group. China Ocean Press, Beijing.

Xie, Z., Shao, H., Chen, F., Chen, Z., Dou, Y., 1985. Transgression since Late Pleistocene in Fujian Coast. International Geological Correlation Programme Project number 200 China working group. China Ocean Press, Beijing. 
Yamaguchi, M., Ota, Y., 2004. Tectonic interpretations of Holocene marine terraces, east coast of Coastal Range, Taiwan. Quat. Int. 115-116, 71.

Yim, W.W.-S., 1999. Radiocarbon dating and the reconstruction of late Quaternary sealevel changes in Hong Kong. Quat. Int. 55, 77-91.

Yim, W.W.S., et al., 2006. Postglacial sea-level changes in the northern South China Sea continental shelf: evidence for a post-8200 calendar yr BP meltwater pulse. Quat. Int. 145-146, 55.

Yim, W.W.-S., Huang, G., 2002. Middle Holocene higher sea-level indicators from the south China coast. Mar. Geol. 182, 225-230.

Yim, W.W.-S., Huang, G., 2003. Reply to “Mid-Holocene higher sea level indicators from the south China coast: a regional perspective" by Baker et al. Mar. Geol.196, 99-101.
Yu, H.-S., 1990. The Pearl River Mouth Basin: a rift basin and its geodynamic relationship with the southeastern Eurasian margin. Tectonophysics 183, 177-186.

Yu, H.-S., 1994. Structure, stratigraphy and basin subsidence of Tertiary basins along the Chinese southeastern continental margin. Tectonophysics 253, 63-76.

Zazo, C., 1999. Interglacial sea levels. Quat. Int. 55, 101-113.

Zhang, Y., Ma, Y., Yang, N., Shi, W., Dong, S., 2003. Cenozoic extensional stress evolution in North China. J. Geodyn. 36 (5), 591.

Zong, Y., 2004. Mid-Holocene sea-level highstand along the Southeast Coast of China. Quat. Int. 117, 55-67. 